\title{
HILGARDIA
}

A Journal of Agricultural Science Publisbed by the California Agricultural Experiment Station

\section{A STUDY OF SOME EGYPTIAN SALINE AND ALKALI SOILS}

WARREN R. SCHOONOVER, M. M. ELGABALY, and $M$. NAGUIB HASSAN

UNIVERSITY OF CALIFORNIA - BERKELEY, CALIFORNIA 
For many centuries, soils of the Nile Valley and delta have been flooded annually by excellent water, and for the past 50 years, they have been irrigated perennially with stored water of somewhat lower quality.

The present survey and field observations, while not permitting broad conclusions, do show some evidence that use of Nile water for perennial irrigation has had an alkalizing influence. The occurrence of high exchangeable sodium content as well as of high salinity was usually associated with high water tables or poor permeability.

The extensive saline areas in the fringe of the delta at or below sea level are capable of reclamation, usually by effective drainage plus leaching. Some portions of these areas contain sufficient exchangeable sodium to make advisable the use of a soil amendment such as gypsum.

Quick-method determinations of electrical conductivity of saturation extracts, soluble divalent cations, gypsum requirement, and cation exchange capacity served to classify the soils, explain observed differences in plant growth and in permeability, and to outline reclamation procedures.

Pot-culture studies indicated that large-sized containers can be used efficiently for studying fine-textured, alkali soils, and that such studies are a useful preliminary to field tests of reclamation procedures. 


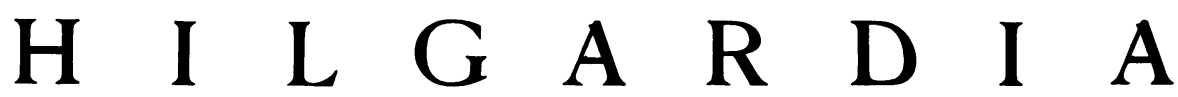

A Journal of Agricultural Science Published by

the California Agricultural Experiment Station

\begin{tabular}{lll}
\hline VoL. 26 & MAY, 1957 & No. 13 \\
\hline
\end{tabular}

\section{A STUDY OF SOME EGYPTIAN SALINE AND ALKALI SOILS ${ }^{1}$

\author{
WARREN R. SCHOONOVER, ${ }^{2}$ M. M. ELGABALY, ${ }^{3}$ \\ and $M$. NAGUIB HASSAN ${ }^{4}$
}

\section{INTRODUCTION}

EGYPT is an arid land where 22 million people are dependent upon production from 6 million irrigated acres. Problems of irrigated agriculture are similar to those of California, where irrigated acreage is not much larger. Rain seldom falls except on a narrow fringe along the coast, and even there, the amounts are so small and scattered that they have little effect upon crop production and bring about no effective leaching of the soil. In the absence of effective leaching from rains, salts from the irrigation waters accumulate to a varying extent, determined by physical and management factors. These salts enter into exchange reactions with the soil clays, resulting in various degrees of alkalization in addition to the salinization. Where salinity and alkali problems have not developed, the soils are unusually productive.

The similarity of alkali problems in Egypt to some of those in California prompted a study of the nature of Egyptian alkali soils. The objectives of the investigation were: (1) to make a survey of the occurrence and nature of saline and alkali soils in Egypt; (2) to make further study of quick methods of analyzing alkali soils; and (3) to study the reclamation of Egyptian alkali soils in pot and field experiments.

\section{EGYPTIAN SOILS}

Egyptian soils of the Nile Valley and delta are mostly recent alluvial deposits of Nile floods. According to Ball (1939), ${ }^{5}$ the soils of the valley and delta have been deposited, at an average rate of $9 \mathrm{~cm}$ per century, from the suspended matter and a portion of the bed load of the Nile, mostly during an annual flood period of four months. Nile solid-matter load arises mainly in the volcanic Abyssinian highlands, and provides only one type of parent soil material. The soils are not uniform in texture, however, because deposition has taken place under varying conditions of topography and rate of flow. There has also been some admixture of wind-blown material from the desert or, along the fringes, of some alluvial material brought in from the adjoining hills by flash floods.

${ }^{1}$ Received for publication August 13, 1956.

${ }^{2}$ Agriculturist, Agricultural Extension, Berkeley; visiting Fulbright Professor of Soils, University of Alexandria, Egypt, 1953-54.

${ }^{3}$ Professor of Soils, University of Alexandria.

${ }^{4}$ Assistant Professor of Soils, University of Alexandria.

"See "Literature Cited" for citations referred to in the text by author and date. 
The depth of the soil deposits indicates that the age of the cultivated lands of the valley is about 10,000 years, and of the delta, less, depending upon location. More ancient deposits were of coarser material. Much of the northern part of the delta must have been deposited under the sea or in salt lakes cut off from the sea by sand bars. In these areas, heavy deposits of shells are frequent, and there has been a sorting of the soil material by wave and current action.

Under the present systems of irrigation, the reported deposition on the basin lands flooded annually in upper Egypt is at the rate of $10.3 \mathrm{~cm}$ per century ; on the perennially irrigated land in upper Egypt, $3.1 \mathrm{~cm}$ per century; and on the perennially irrigated lands of the delta, only $0.6 \mathrm{~cm}$ per century.

The nature of the suspended matter, not including the bottom load of sand and silt, is as follows:

Per cent

Coarse sand, more than $0.2 \mathrm{~mm} \ldots \ldots \ldots \ldots \ldots \ldots \ldots . \ldots . \ldots . \ldots$

Fine sand, 0.2 to $0.02 \mathrm{~mm} \ldots \ldots \ldots \ldots \ldots \ldots \ldots \ldots \ldots$

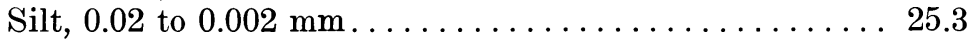

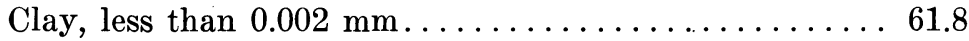

(Colloidal matter is 12 per cent of the clay fraction.)

The exchangeable bases in the suspended matter in milliequivalents (m.e.) per $100 \mathrm{gm}$ air-dried soil are reported by Ball (1939) as follows:

$\begin{array}{cccccc}\mathrm{Ca} & \mathrm{Mg} & \mathrm{K} & \mathrm{Na} & \mathrm{T} \text { tal } & \mathrm{Ex} \mathrm{Mg} / \mathrm{Ca} \\ 37.2 & 13.4 & 1.0 & 0.3 & 51.9 & 0.35\end{array}$

The normal soils take their characteristics from the suspended matter, and thousands of years of farming seem to have produced little change, as shown by analyses, other than a slight drop in the total $\mathrm{P}_{2} \mathrm{O}_{5}$ and a small downward migration of magnesium.

Khadr (1953) reported exchangeable cation analyses of several Egyptian soils. Cation exchange capacities (C.E.C.) and exchangeable magnesium/ calcium ratios ( $\mathrm{Ex} \mathrm{Mg} / \mathrm{Ca}$ ) for three of these soils are shown in table 1 . It is only the soil deposited in the brackish waters of Lake Mariout and subsequently reclaimed by drainage and leaching which differs greatly from the suspended matter of the Nile.

Gracie et al. (1934) have divided Egyptian alkali or "infertile soils" into two categories, "black alkali" and "gypsum veined," described as follows: Black alkali: Highly dispersed with dominant exchangeable base sodium; increased insoluble calcium and magnesium compounds, calcium as carbonate and magnesium as silicate; soluble salts low, but $\mathrm{CO}_{3}$ and $\mathrm{HCO}_{3}$ relatively high. Gypsum veined: The outstanding feature is a dispersed and almost impermeable layer on top of a gypsiferous layer of good structure, with some evidence of high magnesium silicate in the dispersed layer.

These workers offer no explanation as to why both types may be found in proximity, although they do say that the black alkali soils are found where the water table is higher. 
TABLE 1

EXCHANGEABLE MAGNESIUM/CALCIUM RATIOS IN TYPICAL EGYPTIAN SOILS

\begin{tabular}{|c|c|c|c|c|c|c|}
\hline \multirow{3}{*}{ Depth } & \multicolumn{6}{|c|}{ Soil number* } \\
\hline & \multicolumn{2}{|r|}{1} & \multicolumn{2}{|r|}{4} & \multicolumn{2}{|r|}{$\dot{s}$} \\
\hline & C.E.C. & $\underset{\text { ratios }}{\mathrm{Ex} \mathrm{Mg} / \mathrm{Ca}}$ & C.E.C. & $\underset{\text { ratios }}{\mathrm{Ex} \mathrm{Mg} / \mathrm{Ca}}$ & C.E.C. & $\underset{\text { ratios }}{\mathrm{Ex} \mathrm{Mg} / \mathrm{Ca}}$ \\
\hline $\mathrm{cm}$ & m.e. $/ 100 \mathrm{gm}$ & & m.e. $/ 100 \mathrm{gm}$ & & m.e. $/ 100 \mathrm{gm}$ & \\
\hline $0-5$. & 47.36 & 0.44 & 39.37 & 0.30 & 43.69 & 0.57 \\
\hline 5-35. & 45.24 & 0.36 & 40.20 & 0.40 & 34.43 & 1.24 \\
\hline $35-65$. & 42.03 & 0.45 & 52.57 & 0.50 & 39.08 & 2.23 \\
\hline $65-95$. & 40.28 & 0.65 & 45.03 & 0.65 & 33.92 & 1.85 \\
\hline
\end{tabular}

* 1 = Basin soil near Esna.

4 = Delta soil from University of Cairo farm, Giza.

5 = Soil from University of Alexandria farm, recently reclaimed from Lake Mariout.

\section{WATER SUPPLY}

Nile water constitutes almost the entire irrigation supply, with only local, exceedingly small supplemental amounts pumped from well or drains. Ball (1939) has assembled many analyses of Nile water for flood season and low season flow. These analyses indicate that the water is of excellent quality, low in total salts, with calcium and magnesium present in adequate amounts relative to the sodium. Eaton (1950) recalculated the data and postulated the theory that Nile water may not be an "excellent" water since it contains sufficient bicarbonate to precipitate all of the calcium and magnesium upon concentration by transpiration and evaporation. The remaining soluble salts would be 100 per cent sodium, about half of which would be carbonate or bicarbonate at flood time, and nearly three quarters at low flow. Eaton calls this "residual sodium carbonate," and claims that such a water may be an important alkalizing agent. Ball's data, as recalculated by Eaton, are shown in table 2.

Flood water is used for an annual irrigation by the basin system, under which the land is kept flooded for many days each flood season when the quality of the water is at its best. Heavy leaching may be expected in most locations. Under these conditions of only one wetting and drying a season

TABLE 2

COMPOSITION OF NILE WATER AT CAIRO

\begin{tabular}{|c|c|c|c|c|c|c|c|c|c|c|}
\hline \multirow{2}{*}{ Source } & \multirow{2}{*}{ Years } & \multicolumn{3}{|c|}{ Cations } & \multicolumn{3}{|c|}{ Anions } & \multirow{2}{*}{$\begin{array}{l}\text { Residual } \\
\mathrm{Na}_{2} \mathrm{CO}_{3}\end{array}$} & \multicolumn{2}{|c|}{ Sodium: } \\
\hline & & $\mathrm{Ca}$ & $\mathrm{Mg}$ & $\mathrm{Na}$ & $\mathrm{HCO}_{3}$ & $\mathrm{SO}_{4}$ & $\mathrm{Cl}$ & & Found & Possible \\
\hline & & $\begin{array}{l}\text { m.e./ } \\
\text { liter }\end{array}$ & $\begin{array}{l}\text { m.e./ } \\
\text { liter }\end{array}$ & $\begin{array}{c}\text { m.e./ } \\
\text { liter }\end{array}$ & $\begin{array}{l}\text { m.e./ } \\
\text { liter }\end{array}$ & $\begin{array}{l}\text { m.e./ } \\
\text { liter }\end{array}$ & $\begin{array}{c}\text { m.e./ } \\
\text { liter }\end{array}$ & $\begin{array}{l}\text { m.e./ } \\
\text { liter }\end{array}$ & per cent & per cent \\
\hline Flood 4 months. & $1906-36$ & 0.64 & 0.57 & 0.50 & 1.44 & 0.16 & 0.14 & 0.23 & 32 & 100 \\
\hline Low water 8 months. & $1906-36$ & 0.87 & 0.72 & 2.04 & 3.03 & 0.23 & 0.46 & 1.44 & 55 & 100 \\
\hline
\end{tabular}


and leaching with water having a sodium percentage of 32 , the $0.23 \mathrm{~m} . e$./liter of residual sodium carbonate in the flood water rarely results in high alkalinity. Egyptians consider the basin soils to be the "normal" soils of their country, and give them a productivity rating of 100 per cent.

The perennially irrigated lands, in contrast, are not heavily irrigated during flood season because that is the principal cropping period. Irrigations are frequent, and the surface soil dries out many times a year and is re-wet with water containing up to 55 per cent sodium and up to $1.44 \mathrm{~m}$.e./liter of residual sodium carbonate. The water supply is calculated to be 6,000 to 6,500 cubic meters per feddan, or a total depth of $1 \frac{1}{2}$ meters. (One feddan equals 1 acre within about 1 per cent.) With this limited water supply used on dense soils in a hot, dry climate, leaching is restricted and often ineffective. Furthermore, the water table is frequently within the root zone of the crops grown. As a consequence, high alkalinity as well as high salinity is fairly common. Egyptians are worried over the future of the lands perennially irrigated with stored water, since there is some evidence of a general decline in their productivity. The greatest area of saline and alkali soils, however, is found in the northern delta where the lands were under the influence of tidal waters during deposition.

\section{METHODS}

Soil analysis methods, to be acceptable, must be capable of appraising and classifying saline and alkali soils according to prevailing definitions. In brief, saline soils contain sufficient soluble salts to impair productivity; alkali or sodic soils contain sufficient exchangeable sodium (Ex Na) in proportion to other cations to impair either soil structure or plant growth; and saline alkali soils combine both characteristics. Saline and alkali soils also show great variability within short distances, so much so that composite samples may have little meaning. Methods should be sufficiently rapid that many samples can be analyzed in view of the extreme variability. It was possible, with the facilities available, to make a reconnaissance survey of saline and alkali soils using so-called quick methods. Such methods (Schoonover, 1952, 1953) have been adapted from standard procedures or developed in the laboratories of the Agricultural Extension Service, University of California. The determinations made included: (1) saturation percentage; (2) $\mathrm{CaCo}_{3}$ by effervescence; (3) electrical conductivity (E.C.) of extract from saturated soil ; (4) soluble calcium in saturation extract by versenate titration, as discussed by Connors (1950), Diehl, Goetz, and Hack (1950), and Cheng and Bray (1951); (5) soluble magnesium in saturation extract (Ca plus $\mathrm{Mg}$ by versenate titration, and $\mathrm{Mg}$ by difference); (6) gypsum requirement (G.R.) ; (7) cation exchange capacity (C.E.C.); and (8) $\mathrm{pH}$ of 1 to 5 water suspension. Facilities were not available for the determination of sodium. No anions were determined since they do not help to classify soils in relation to the definitions.

Electrical conductivity of the saturation extract (E.C.) has often been used as a measure of the total salinity. Concentrations are usually reported as millimhos per centimeter, or E.C. $\times 10^{3}$. We shall report as E.C. $\times 10^{4}$ since this value is approximately equal to the concentration of total salts in 
m.e./liter. Mr. J. C. Martin, Chemist, California Agricultural Experiment Station, kindly supplied us with analyses of 96 California alkali soils which show relationships between E.C. $\times 10^{4}$ and total determined anions, as follows:

Mean E.C. $\times 10^{4} \quad$ Mean cone. total anions (m.e./liter)

96.6

41.8
Ratio (anions/E.C.)

\begin{tabular}{|c|c|c|c|}
\hline 16 soils, high $\mathrm{Ex} \mathrm{Na}$ & 92 & 96.6 & 1.05 \\
\hline $\begin{array}{r}27 \text { soils, } \mathrm{Na} 40 \%, \mathrm{Ca} 45 \%, \\
\mathrm{Mg} 15 \% \ldots \ldots \ldots \ldots\end{array}$ & 55 & 65.7 & 1.19 \\
\hline $\begin{array}{r}27 \text { soils, } \mathrm{Na} 30 \%, \mathrm{Ca} 61 \% \text {, } \\
\quad \mathrm{Mg} 9 \% \ldots \ldots \ldots \ldots \ldots\end{array}$ & 36.1 & 41.8 & 1.16 \\
\hline $\begin{array}{l}\text { Same soils on basis of } 1: 10 \\
\text { dilution of saturation } \\
\text { extract } \ldots \ldots \ldots \ldots \ldots\end{array}$ & & & 0.91 \\
\hline 26 soils, high mixed salts. & 31.1 (1:10 basis $)$ & 30.5 & 0.98 \\
\hline
\end{tabular}

(See also Richards, 1954 , p. 12 ). E.C. $\times 10^{4}$ will, therefore, be considered our estimate of total cations in m.e./liter. In all cases where the estimated cations in the saturation extract exceeded 40 or 50 m.e. per liter they were diluted and redetermined.

These data indicate a sufficiently close realtionship between E.C. and salt concentration to classify saline soils in relation to productivity. The relationship permits only a poor estimate of soluble sodium by subtracting the determined calcium and magnesium from the estimated cations. This situation precludes an estimate of the exchange status of the soil by use of the "sodium-adsorption ratio" (S.A.R.) concept introduced by the U. S. Salinity Laboratory (see Richards, 1954). Calculation of this ratio would require a more accurate value for total cations than the estimate from E.C., and would also require the determination of sodium. Fortunately, two quickly made determinations, gypsum requirement (G.R.) and cation exchange capacity (C.E.C.), provide a much more accurate estimate of the sodium exchange ( $\mathrm{Ex} \mathrm{Na}$ ) status of the soil without requiring the direct determination of sodium.

The gypsum requirement method was first proposed as an estimate of the amount of gypsum to use in reclamation tests. It has proved quite accurate, at least in certain soils, as a measure of exchangeable sodium. Figure 1 shows the relationship between G.R. and Ex Na (ammonium acetate method for $\mathrm{Ex} \mathrm{Na}$ ) in soils from central California. The fact that calcium from a saturated gypsum solution will replace sodium almost quantitatively in a soil without replacing potassium is shown by Bower, Moodie, Orth, and Gschwend (1954, table 2). They also state that the gypsum requirement and the exchangeable sodium content of the 0 - to 12-inch layers of plots were highly correlated $\left(\mathrm{n}^{2}=94.3\right.$ per cent $)$.

Cation exchange capacity was determined by a new method developed for use in this study. The method is based upon saturating a soil sample with barium and then determining the amount of calcium from a saturated solution of gypsum required to replace the barium. This is done by a modification of the G.R. method applied to the barium-saturated sample. Details of 
the G.R. and C.E.C. methods are given in the Appendix, page 594. Both values are expressed as m.e. per $100 \mathrm{gm}$ of soil. Since the G.R. closely approximates the Ex Na, G.R./C.E.C. $\times 100$ may be regarded as a good estimate of exchangeable sodium percentage.

These quick methods, requiring little equipment, do appraise saline and

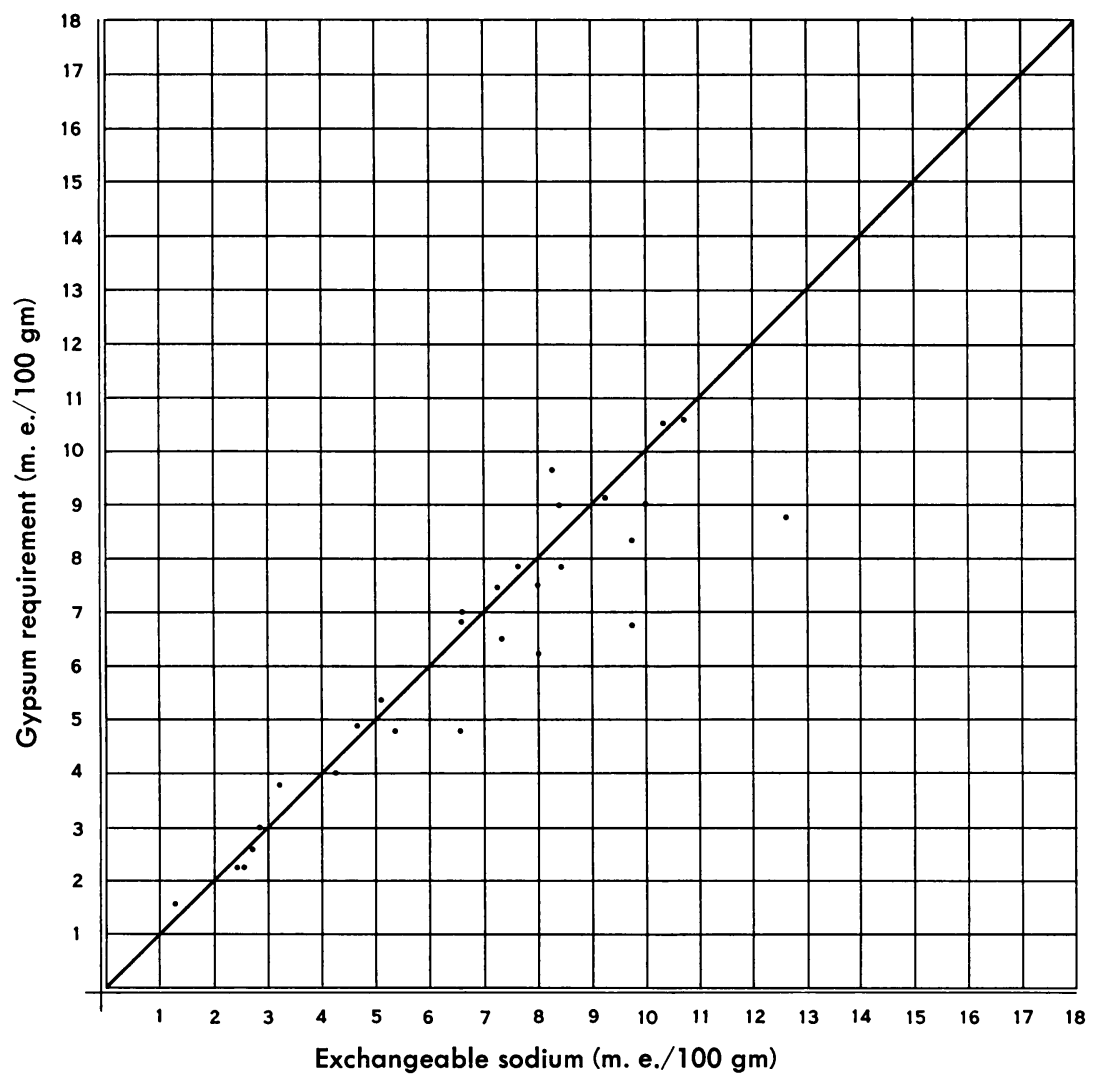

Fig. 1. Relationship between gypsum requirement and exchangeable sodium.

alkali soils in relation to the definitions since: (1) E.C. is a measure of salinity; (2) G.R./C.E.C. $x 100$ is a measure of Ex Na status. The other determinations provide confirmation. If soluble calcium and magnesium are low in relation to E.C., the estimated Ex Na percentage and the $\mathrm{pH}$ should be high, and vice versa. The authors believe that these methods do portray the characteristics of the soils studied in this survey.

\section{SURVEY OF SALINITY AND ALKALI CONDITIONS}

Field trips were made to typical areas, mostly in the northern and north central portion of the Nile Delta. Soil samples were collected to represent various observed conditions of the occurrence of salinity and alkali. The investigators endeavored to get one complete set of samples to a depth of 1 
meter or to the water table, at each farm visited. Since there was little evidence of profile development in most of the locations, the sub-samples were divided arbitrarily. In the few cases where some differentiation was possible, the sub-samples were taken to represent the situation. No composite samples were taken. Each sample represents a condition noted at the time of sampling. In addition to the full sample sets, many other samples were taken to lesser depths to study observed differences in crops. Some samples represent the principal root zone of shallow-rooted halophytes found growing at the sampling location. The areas studied are shown on the map (fig. 2 ).

\section{Soils of the Lakes Region, Northern Delta}

The largest area of Egyptian land capable of reclamation, and easily served with irrigation water, consists of lands near or below sea level and on the borders of, or under, shallow portions of brackish lakes. The area of potential good land is estimated at about one million feddans. It will require diking, drainage, and reclamation measures, such as leaching, and possibly the use of soil amendments. A considerable acreage of such land has been reclaimed during the last 50 years, much of it highly productive.

Location A (fig. 2) represents the area being reclaimed from Lake Mariout. The soil material was deposited in the lake by Nile floods, and has undergone some sorting by wave and current action. The elevation is about 2 meters below sea level. The area was drained 20 years ago, and drainage is maintained by pumping from the main drainage canal into the lake. Portions of the farm which have been adequately leached, and where the water table has been kept below 1 meter, are highly productive.

The soil is calcareous, containing much coarse shell, and in some places is fairly sandy. It also is exceedingly variable. Gypsum requirement determinations were made on 26 samples of the surface $(20 \mathrm{~cm}$ depth) taken from an area about one-half acre in extent. The G.R. determinations varied from 0 to $9.6 \mathrm{~m} . e . / 100 \mathrm{gm}$. Six were 0 , eight were between 5 and 8 , and three were above 8 . This variability may have been due, in part, to leveling and to spreading out soil from the tile lines. The area was unproductive even though it had been leached until nearly free from salt. Berseem (Trifolium Alexandrinum) had been planted, and had failed except in a few spots. There was no pattern of high or low G.R.

Fourteen samples from six locations in the unreclaimed area were analyzed, with results as shown in table 3 .

Area B (fig. 2) represents the saline area on the fringe of Lake Idku. The land is very flat, and falls gently toward the present lake about 20 kilometers to the north. The water table is at a depth of 1 to 1.5 meters. The land is drained with surface drains and field laterals. The latter are only $75 \mathrm{~cm}$ deep, which is insufficient for good drainage. All of the land in the vicinity of this farm shows evidence of high salinity. Leaching has been insufficient for any part of this farm to be very productive. The soil appears to be Nile silt with a mixture of various amounts of fine sand. Results of the analyses are shown in table 4.

Area C (fig. 2) is representative of the western part of the large Lake Burullus area which lies between the two branches of the Nile. The farm 


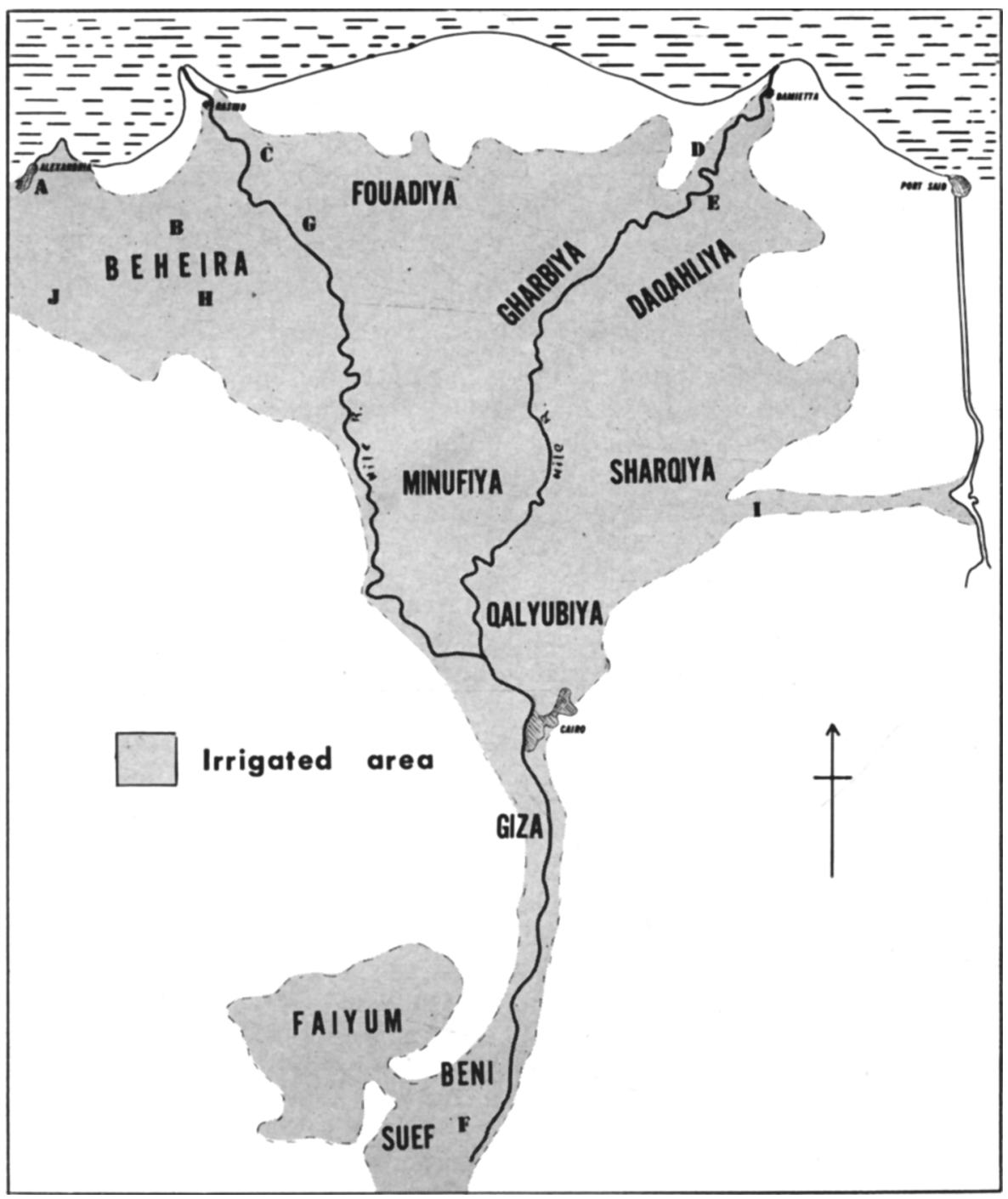

Fig. 2. Soils of the lakes region, northern delta: A. University of Alexandria farm, southeast of city, near Lake Mariout; B. farm of Dr. B. A. Boctor, northeast of Abu Humus, near Lake Idku; $C$. farm of Mr. Abou Youssef, northeast of Edfina, near Lake Burullus; D. Egyptian government farm at Kafr Sa'd, east of Lake Burullus ; $E$. Egyptian government farm at el Sirw, adjacent Lake Manzala. Nile Valley soils: F. Farm at Bush, Beni Suef. Soils of the north central delta: G. Farm of Dr. Hussein, northeast of Disuq; $H$. el Defrawi farm near el Basatin, southwest of Damanhour. Soils partly of desert origin: I. Egyptian government farm at el Tell el Kebir; J. Tawil farm at Kom el Hanash. 
of 170 feddans is very near the lake, and has been under intensive reclamation for four years. The water table is at a depth of about 1 meter. Many crops (peas, horse beans, wheat, barley, and berseem) seemed to be thriving, but there were numerous bad spots in the fields.

There is a 30 -acre orchard consisting of pears, peaches, plums, limes, lemons, and a few oranges. The trees showed signs of nutritional disturbances. Peaches and pears have grown fairly well, plums have grown poorly. Limes have made the best growth of the citrus species, and oranges the poorest. Zinc, manganese, and iron deficiencies were noted in citrus trees. Results of analyses are shown in table 5.

TABLE 3

RESULTS ON SOILS FROM AREA A

\begin{tabular}{|c|c|c|c|c|c|c|c|c|}
\hline Location* & Depth & Est. cations & Sol. Ca & Sol. Mg & G. R. & C.E.C. & Est. Ex Na & pH (1 to 5$)$ \\
\hline & $\mathrm{cm}$ & m.e./liter & m.e./liter & m.e./liter & m.e. $/ 100 \mathrm{gm}$ & m.e. $/ 100 \mathrm{gm}$ & per cent & \\
\hline $1 \mathrm{a} \ldots$ & $0-5$ & 2,800 & 250 & 440 & -24.0 & $\ldots$ & $\ldots$ & 7.7 \\
\hline $1 \mathrm{~b} \ldots$ & $5-25$ & 700 & 30 & 15 & 6.0 & 18.5 & 32.3 & 8.6 \\
\hline $1 \mathrm{c} \ldots \ldots \ldots$ & $25-50$ & 500 & 13 & 37 & 11.0 & 20.0 & 55.0 & 9.0 \\
\hline $2 a$. & $0-5$ & 5,000 & 170 & 902 & -63.0 & $\ldots$ & 0.0 & 7.8 \\
\hline $2 b .$. & $5-25$ & 1,100 & 72 & 172 & -5.0 & 33.5 & 0.0 & 8.4 \\
\hline $2 c \ldots$ & $25-50$ & 930 & 47 & 131 & 4.0 & 35.5 & 11.2 & 8.3 \\
\hline $3 a$. & $0-20$ & 15 & 4 & 6 & 0.8 & 37.0 & 2.5 & 8.7 \\
\hline $3 b$. & $20-40$ & 15 & 2 & 4 & 0.8 & 22.5 & 3.5 & 9.0 \\
\hline $4 a \ldots$ & $0-25$ & 139 & 4 & 10 & 5.6 & 14.4 & 38.0 & 9.6 \\
\hline $4 b \ldots \ldots \ldots$ & $25-50$ & 260 & 5 & 24 & 12.0 & 26.5 & 45.2 & 9.4 \\
\hline $5 \mathrm{a} \ldots \ldots \ldots$ & $0-25$ & 195 & 5 & 16 & 8.8 & 23.0 & 38.5 & 9.5 \\
\hline $5 \mathrm{~b} \ldots \ldots \ldots$ & $25-50$ & 255 & 5 & 14 & 11.6 & 23.0 & 50.2 & 9.4 \\
\hline $6 \mathrm{a} \ldots \ldots \ldots$ & $0-25$ & 125 & 12 & 26 & 4.0 & 33.5 & 11.9 & 8.7 \\
\hline $6 \mathrm{~b} \ldots \ldots \ldots$ & $25-50$ & 115 & 7 & 24 & 5.6 & 31.5 & 17.8 & 8.9 \\
\hline
\end{tabular}

* 1. Salicornia herbaria prevalent. Berseem planted, but failed.

2. Salicornia herbaria prevalent. No crops planted.

3. Erigeron Canadensis prevalent. No crop planted.

4. Inula sp. prevalent. Berseem planted, but failed.

5. Saueda fructicora prevalent. No crop planted.

6. Cochia indica prevalent. Sample from edge of drain.

The Egyptian government farm at Kafr Sa'd was selected as representative of Area D (fig. 2). The land in this farm has been under reclamation for 16 years, but far less progress has been made than in Area C. This is probably because the water table has remained high, having fluctuated between 40 and $60 \mathrm{~cm}$ from the surface. At the time of sampling, water was standing at $45 \mathrm{~cm}$ from the surface in the field drains. Berseem was growing fairly well near the drains, but had failed completely midway between. Results of analyses are shown in table 6 .

Area E (fig. 2) represents lands east of the Damietta branch of the Nile and adjacent to Lake Manzala. The land is approximately at sea level. A main drain passes through the area. Laterals are insufficient to pull the water table below $80 \mathrm{~cm}$, and it is sometimes at $60 \mathrm{~cm}$. The condition of crops indicated that reclamation has been more successful here than in Area D. Because 
of rain, it was possible to take samples from only one location which was in the early stages of reclamation. The water table was approximately $75 \mathrm{~cm}$ from the surface. Crystals of gypsum were encountered just above the water table. Results of analyses are shown in table 7.

TABLE 4

RESULTS ON SOILS FROM AREA B

\begin{tabular}{|c|c|c|c|c|c|c|c|c|}
\hline Location* & Depth & Est. cations & Sol. Ca & Sol. Mg & G. R. & C.E.C. & Est. Ex Na & $\mathrm{pH}$ (1 to 5$)$ \\
\hline & $\mathrm{cm}$ & m.e./liter & m.e./liter & m.e./liter & m.e. $/ 100 \mathrm{gm}$ & m.e. $/ 100 \mathrm{gm}$ & per cent & \\
\hline $1 a .$. & $0-20$ & 170 & 30 & 25 & 1.2 & 33 & 3.6 & 8.2 \\
\hline $1 b \ldots$ & $20-40$ & 350 & 39 & 46 & 0.0 & 25.5 & 0.0 & 8.5 \\
\hline $2 a \ldots$ & $0-20$ & 80 & 26 & 17 & -0.8 & 34 & 0.0 & 8.3 \\
\hline $2 \mathrm{~b} \ldots$ & $20-40$ & 230 & 29 & 32 & 0.0 & 21.5 & 0.0 & 8.4 \\
\hline $3 \ldots \ldots$ & $0-15$ & 32 & 12 & 7 & -0.4 & $\ldots$ & $\ldots$ & 8.3 \\
\hline $4 \ldots \ldots \ldots$ & $0-15$ & 58 & 28 & 13 & -2.8 & $\ldots$ & $\ldots$ & 8.2 \\
\hline $5 \ldots \ldots \ldots$ & $0-15$ & 270 & 42 & 44 & -1.2 & $\ldots$ & $\ldots$ & 8.1 \\
\hline $6 \ldots \ldots$ & $0-15$ & 180 & 33 & 27 & -0.8 & $\ldots$ & $\ldots$ & 8.4 \\
\hline $7 \ldots \ldots \ldots$ & $0-20$ & 340 & 52 & 52 & -5.6 & $\ldots$ & $\ldots$ & 8.5 \\
\hline $8 \ldots \ldots$ & $0-5$ & 130 & 31 & 23 & -1.2 & $\ldots$ & $\ldots$ & 8.3 \\
\hline $9 \ldots \ldots$ & $0-25$ & 1,135 & 65 & 14 & -12.0 & $\ldots$ & $\ldots$ & 8.5 \\
\hline $10 \ldots \ldots$ & $0-25$ & 2,450 & 140 & 230 & -4.8 & $\ldots$ & $\ldots$ & 8.3 \\
\hline $11 a$. & $5-25$ & 640 & 52 & 128 & -4.0 & 15 & 0.0 & $\ldots$ \\
\hline $11 b \ldots \ldots$ & $25-45$ & 200 & 56 & 116 & -3.2 & 19 & 0.0 & $\ldots$ \\
\hline $11 \mathrm{c} \ldots \ldots$ & $45-65$ & 1,000 & 60 & 228 & -10.8 & 23.5 & 0.0 & $\ldots$ \\
\hline $11 d \ldots \ldots$ & $65-90$ & 1,000 & 56 & 216 & -2.8 & 30 & 0.0 & $\ldots$ \\
\hline $12 \mathrm{a} .$. & $0-25$ & 110 & 26 & 14 & 2.8 & 27 & 10.4 & $\ldots$ \\
\hline $12 \mathrm{~b} \ldots \ldots$ & $25-50$ & 160 & 26 & 19 & 3.6 & 16 & 22.4 & $\ldots$ \\
\hline $12 \mathrm{c} \ldots \ldots \ldots$ & $50-75$ & 350 & 33 & 31 & 8.8 & 22.5 & 39.0 & $\ldots$ \\
\hline $12 \mathrm{~d} \ldots$ & $75-100$ & 590 & 47 & 65 & 5.6 & 25 & 22.3 & $\ldots$ \\
\hline
\end{tabular}

*1. Berseem growing very poorly.

2. Berseem growing fairly well.

3 to 8 . Samples taken around roots of various salt-loving plants.

9,10 . Virgin land being prepared for leaching.

11. Lightly leached.

12. Heavily leached; believed by owner to be ready for planting.

\section{Nile Valley Soils}

Area F (fig. 2) is a Nile Valley area, the soils of which have been deposited slowly by floods, and no such swampy condition has ever existed as that found in the northern lakes regions. This particular area has been under the influence of a high water table for several years because of the establishment of a dead-end drain nearby. A recently developed barren spot, several feddans in extent, appears to be increasing in size. The water table was 40 to $50 \mathrm{~cm}$ from the surface. Samples were taken at two locations about 3 meters apart. Results of analyses are shown in table 8.

\section{Soils of the North Central Delta}

Many areas in the delta show evidences of salinity and alkali which appear to be localized and associated with high water tables near canals or drains.

The soil at Area G (fig. 2) is a tough clay exhibiting spots of poor structure 
TABLE 5

RESULTS ON SOILS FROM AREA C

\begin{tabular}{|c|c|c|c|c|c|c|c|c|}
\hline Location* & Depth & Est. cations & Sol. Ca & Sol. $\mathbf{M g}$ & G. R. & C.E.C. & Est. Ex Na & $\mathrm{pH}(1$ to 5$)$ \\
\hline & $\mathrm{cm}$ & m.e./liter & m.e./liter & m.e./liter & m.e. $/ 100 \mathrm{gm}$ & m.e. $/ 100 \mathrm{gm}$ & per cent & \\
\hline $1 \mathrm{a} .$. & $0-20$ & 37.0 & 17.7 & 19.1 & -2.8 & 37.5 & 0.0 & 8.5 \\
\hline $1 b$. & $20-50$ & 22.0 & 1.6 & 5.1 & 2.2 & 34.0 & 6.5 & 8.8 \\
\hline $1 \mathrm{c} \ldots$ & $50-75$ & 21.3 & 0.5 & 1.5 & 10.4 & 43.5 & 24.0 & 9.2 \\
\hline $1 \mathrm{~d} \ldots \ldots \ldots$ & $75-100$ & 27.5 & 0.6 & 1.1 & 12.2 & 39.0 & 31.2 & 9.3 \\
\hline $2 \mathbf{a}$. & $0-35$ & 15.6 & 2.2 & 2.2 & 2.8 & 41.0 & 6.8 & 8.5 \\
\hline $2 b$. & $35-85$ & 17.8 & 0.7 & 0.3 & 9.4 & 34.5 & 27.2 & 9.3 \\
\hline $2 c \ldots$ & $85-100$ & 43.0 & 0.7 & 1.3 & 19.6 & 53.0 & 37.0 & 9.1 \\
\hline $3 \mathbf{a}$. & $0-20$ & 86.0 & 13.2 & 19.4 & 3.6 & 51.0 & 7.1 & 8.3 \\
\hline $3 b$. & $20-40$ & 175.0 & 14.3 & 29.5 & 6.0 & 47.0 & 12.8 & 8.4 \\
\hline $4 a$. & $0-20$ & 58.0 & 11.4 & 13.8 & 2.2 & 53.0 & 4.2 & 8.4 \\
\hline $4 \mathrm{~b}$ & $20-40$ & 82.0 & 10.6 & 19.4 & 4.8 & 46.5 & 10.2 & 8.4 \\
\hline $5 \mathrm{a} \ldots \ldots \ldots$ & $0-20$ & 34.0 & 6.4 & 6.9 & 2.4 & 54.0 & 4.4 & 8.3 \\
\hline $5 \mathrm{~b} \ldots \ldots \ldots$ & $20-40$ & 34.5 & 2.1 & 3.3 & 8.0 & 46.0 & 17.4 & 9.0 \\
\hline
\end{tabular}

* 1. Plum orchard. Horizons separated according to texture: $0-20 \mathrm{~cm}$, loam; $20-50 \mathrm{~cm}$, clay; $50-75 \mathrm{~cm}$, clay or clay loam: 75-100 cm. fine sandy loam. This location had been treated with gypsum three vears earlier at the rate of 12 tons per acre.

2. Lemon orchard. Horizons divided according to changes in color: $0-35 \mathrm{~cm}$, black clay loam: $35-85 \mathrm{~cm}$, light brown; 85-100 cm, lighter color, very wet, sticky, and highly dispersed. Water table at $100 \mathrm{~cm}$.

3 . Poor horse beans.

4. Fair horse beans.

5. Good horse beans.

TABLE 6

RESULTS ON SOILS FROM AREA D

\begin{tabular}{|c|c|c|c|c|c|c|c|c|}
\hline Location* & Depth & Est. cations & Sol. Ca & Sol. $\mathrm{Mg}$ & G. R. & C.E.C. & Est. Ex Na & $\mathrm{pH}(1$ to 5$)$ \\
\hline & $\mathrm{cm}$ & m.e./liter & m.e./liter & m.e./liter & m.e. $/ 100 \mathrm{gm}$ & m.e. $/ 100 \mathrm{gm}$ & per cent & \\
\hline $1 \ldots \ldots \ldots$ & $0-5$ & 127 & 9.0 & 15.4 & 7.0 & .. & $\ldots$ & 9.0 \\
\hline $2 a \ldots$ & $0-5$ & 640 & 60.0 & 149.0 & -2.6 & .. & 00.0 & 8.1 \\
\hline $2 \mathrm{~b}$. & $0-25$ & 444 & 20.0 & 63.0 & 8.2 & 31 & 26.4 & 8.7 \\
\hline $2 c \ldots$ & $25-50$ & 524 & 13.0 & 45.0 & 9.8 & 25 & 39.2 & 9.1 \\
\hline $3 a \ldots \ldots \ldots$ & $0-25$ & 45 & 1.7 & 3.9 & 8.2 & 37 & 22.4 & 9.3 \\
\hline $3 b \ldots \ldots$ & $25-50$ & 38 & 1.1 & 1.9 & 9.0 & 35 & 25.6 & 9.5 \\
\hline $4 \mathrm{a} .$. & $0-25$ & 80 & 2.8 & 5.0 & 11.4 & 34 & 33.5 & 9.5 \\
\hline $4 b \ldots \ldots$ & $25-50$ & 62 & 0.7 & 1.4 & 14.2 & 31 & 45.8 & 9.5 \\
\hline
\end{tabular}

* 1. Crust 0-5 cm; some salt-tolerant vegetation present.

2. Midway between drains: no growth of any kind.

3. Near surface drain; good berseem.

4. Two meters farther from drain; poor berseem.

TABLE 7

RESULTS ON SOILS FROM AREA E

\begin{tabular}{|c|c|c|c|c|c|c|c|c|}
\hline Location & Depth & Est. cations & Sol. Ca & Sol. Mg & G. R. & C.E.C. & Est. Ex Na & $\mathrm{pH}$ (1 to 5$)$ \\
\hline & $\mathrm{cm}$ & m.e./liter & m.e./liter & m.e./liter & m.e. $/ 100 \mathrm{gm}$ & m.e. $/ 100 \mathrm{gm}$ & per rent & \\
\hline $1 \mathrm{a}$. & $0-25$ & 276 & 27 & 46 & 3.6 & 39.0 & 9.4 & 8.5 \\
\hline $1 b$. & $25-50$ & 510 & 28 & 76 & 4.2 & 32.5 & 12.8 & 8.2 \\
\hline $1 \mathrm{c} \ldots \ldots \ldots$ & $50-75$ & 640 & 59 & 99 & -2.2 & 31.0 & 0.0 & 8.4 \\
\hline
\end{tabular}


TABLE 8

RESULTS ON SOILS FROM AREA F

\begin{tabular}{|c|c|c|c|c|c|c|c|c|}
\hline Location* & Depth & Est. cations & Sol. Ca & Sol. $\mathrm{Mg}$ & G. R. & C.E.C. & Est. Ex Na & $\mathrm{pH}(1$ to 5$)$ \\
\hline & $\mathrm{cm}$ & m.e./liter & m.e./liter & m.e./liter & m.e. $/ 100 \mathrm{gm}$ & m.e. $/ 100 \mathrm{gm}$ & per cent & \\
\hline $1 a$. & $0-25$ & 16.1 & 4.6 & 2.9 & 0.0 & 39.0 & 0 & 8.7 \\
\hline $1 b$. & 25-50 & 11.2 & 3.1 & 2.0 & 0.0 & 33.5 & 0 & 8.8 \\
\hline $2 a$. & $0-25$ & 820.0 & 30.0 & 52.0 & 8.8 & 28.5 & 29 & 8.7 \\
\hline $2 \mathrm{~b}$. & $25-50$ & 242.0 & 20.0 & 22.0 & 10.0 & 24.5 & 33 & 8.7 \\
\hline
\end{tabular}

*1. Fxcellent berseem.

2. Barren except for a few sprigs of saltgrass.

TABLE 9

RESULTS ON SOILS FROM AREA G

\begin{tabular}{|c|c|c|c|c|c|c|c|c|}
\hline Location* & Depth & Est. cations & Sol. Ca & Sol. $\mathbf{M g}$ & G. R. & C.E.C. & Est. Ex Na & $\mathrm{pH}(1$ to 5$)$ \\
\hline & $\mathrm{cm}$ & m.e./liter & m.e./liter & m.e./liter & m.e. $/ 100 \mathrm{gm}$ & m.e. $/ 100 \mathrm{gm}$ & per cent & \\
\hline $1 \mathrm{a} \ldots \ldots$ & $0-5$ & 200 & 46.0 & 39.5 & 0.0 & .. & 0.0 & 8.2 \\
\hline $1 b \ldots$ & $5-30$ & 363 & 93.0 & 82.0 & -4.0 & 39.0 & 0.0 & 8.0 \\
\hline $1 \mathrm{c} \ldots$ & $30-60$ & 194 & 28.0 & 30.0 & 4.8 & 40.0 & 12.0 & 8.5 \\
\hline 1d. . & $60-85$ & 186 & 23.5 & 23.5 & 6.8 & 43.5 & 15.6 & 8.6 \\
\hline $2 \mathrm{a}$. & $0-15$ & 242 & 56.0 & 53.0 & -1.2 & 46.0 & 0.0 & 8.3 \\
\hline $2 \mathrm{~b} .$. & $15-30$ & 141 & 26.5 & 25.4 & 2.8 & 47.0 & 5.9 & 8.4 \\
\hline
\end{tabular}

* 1 . Poor cotton. Perched water table at $60 \mathrm{~cm}$ on top of layer of clay showing blue mottling.

2. Compacted structure; very poor cotton.

TABLE 10

RESULTS ON SOILS FROM AREA H

\begin{tabular}{|c|c|c|c|c|c|c|c|c|}
\hline Location* & Depth & Est. cations & Sol. Ca & Sol. $\mathbf{M g}$ & G. R. & C.E.C. & Est. Ex Na & $\mathrm{pH}$ (1 to 5$)$ \\
\hline & $\mathrm{cm}$ & m.e./liter & m.e./liter & m.e./liter & m.e. $/ 100 \mathrm{gm}$ & m.e. $/ 100 \mathrm{gm}$ & per cent & \\
\hline $1 a .$. & $0-15$ & 28 & 0.85 & 0.35 & 9.6 & 32 & 30 & 9.40 \\
\hline $1 b \ldots$ & $15-35$ & 40 & 0.65 & 0.25 & 18.4 & 34 & 54 & 9.65 \\
\hline $1 \mathrm{c} \ldots \ldots \ldots$ & $35-60$ & 36 & 0.55 & $\operatorname{tr}$ & 24.0 & 38 & 64 & 9.80 \\
\hline $1 d \ldots \ldots \ldots$ & $60-90$ & 22 & 0.40 & 0.0 & 10.4 & 17 & 61 & 10.00 \\
\hline $2 \mathrm{a}$. & $0-10$ & 16 & 1.50 & 0.9 & 3.6 & 33 & 11 & 8.80 \\
\hline $2 b \ldots$ & $10-25$ & 20 & 1.50 & 1.1 & 4.8 & 37 & 13 & 9.15 \\
\hline $2 c \ldots \ldots$ & $25-60$ & 31 & 1.00 & 0.1 & 12.4 & 25 & 49 & 9.60 \\
\hline $3 \mathbf{a}$. & $0-25$ & 56 & 0.60 & 0.1 & 21.6 & 39 & 55 & 9.60 \\
\hline $3 \mathrm{~b}$. & $25-55$ & 34 & 0.60 & 0.0 & 28.0 & 40 & 70 & 9.95 \\
\hline $4 a$. & $0-3$ & 1,500 & 35.00 & 10.0 & 13.6 & 29 & 47 & 9.00 \\
\hline $4 b$. & $5-20$ & 310 & 6.00 & 4.0 & 20.0 & 33 & 60 & 9.50 \\
\hline
\end{tabular}

* 1 . Berseem planted, but failed.

2. Berseem germinated and grew well for a while, but died later.

3. No crops growing. Cotton failed to germinate previous year. Tomatoes nearby almost complete failure.

4. Field prepared for leaching; surface crust of white salt. 
TABLE 11

RESULTS ON SOILS FROM AREA I

\begin{tabular}{|c|c|c|c|c|c|c|c|c|}
\hline Location* & Depth & Est. cations & Sol. Ca & Sol. $\mathrm{Mg}$ & G. R. & C.E.C. & Est. Ex Na & $\mathrm{pH}(1$ to 5$)$ \\
\hline & $\mathrm{cm}$ & m.e./liter & m.e./liter & m.e./liter & m.e. $/ 100 \mathrm{gm}$ & m.e. $/ 100 \mathrm{gm}$ & per sent & \\
\hline $1 \mathrm{a} \ldots \ldots \ldots$ & $0-25$ & 40 & 1.75 & 2.0 & 10.8 & 18.5 & 59.0 & 9.6 \\
\hline 1b. & $25-50$ & 31 & 12.4 & 10.4 & 0.8 & 15.5 & 5.1 & 8.4 \\
\hline $1 c .$. & $50-75$ & 25 & 2.2 & 7.2 & 1.2 & 12.0 & 10.0 & 8.5 \\
\hline $2 \ldots \ldots \ldots \ldots$ & $0-15$ & 48 & 11.6 & 12.6 & 2.4 & 31.0 & 7.2 & 8.4 \\
\hline $3 \ldots$ & $0-15$ & 60 & 1.0 & 1.2 & 5.2 & 31.0 & 16.7 & 9.0 \\
\hline $4 \mathrm{a} \ldots$ & $0-20$ & 375 & 10.0 & 18.0 & 20.8 & 34.5 & 60.0 & 9.3 \\
\hline $4 b \ldots \ldots \ldots$ & $20-40$ & 66 & 1.5 & 1.5 & 24.8 & 39.0 & 63.5 & 9.5 \\
\hline
\end{tabular}

* 1. Wet soil; water table $50 \mathrm{~cm}$ or less. Surface soil black; subsoil saturated and bluish-gray. No crop growing. 2. Across road from location 1 . Berseem started well.

3. Adjacent location 2. Berseem dying in seedling stage.

4. Barren area 2 miles southeast, near duck pond. Land never farmed, but produces few sprigs of saltgrass.

TABLE 12

RESULTS ON INTERMEDIATE SOILS FROM AREA J

\begin{tabular}{|c|c|c|c|c|c|c|c|c|}
\hline Location* & Depth & Est. cations & Sol. Ca & Sol. Mg & G. R. & C.E.C. & Est. Ex Na & $\mathrm{pH}(1$ to 5$)$ \\
\hline & $\mathrm{cm}$ & m.e./liter & m.e./liter & m.e./liter & m.e. $/ 100 \mathrm{gm}$ & m.e. $/ 100 \mathrm{gm}$ & per cent & \\
\hline $1 \ldots$ & at 180 & 120 & 25 & 19 & 1.2 & $\cdots$ & $\ldots$ & 8.2 \\
\hline $2 a$. & $0-30$ & 580 & 46 & 54 & -0.4 & 16.2 & 0.0 & 8.2 \\
\hline $2 b \ldots$ & $30-50$ & 210 & 25 & 21 & 4.8 & 21.0 & 22.8 & 8.6 \\
\hline $2 \mathrm{c} \ldots$ & $50-75$ & 238 & 33 & 24 & 4.0 & 20.0 & 20.0 & 8.3 \\
\hline $2 d \ldots \ldots \ldots$ & $75-100$ & 830 & 140 & 149 & -9.6 & 18.4 & 0.0 & 8.0 \\
\hline $3 a$. & $0-15$ & 77 & 31 & 14 & 1.2 & 28.5 & 4.2 & 8.35 \\
\hline $3 b \ldots$ & $15-35$ & 150 & 38 & 29 & 0 & 21.0 & 0.0 & 8.05 \\
\hline $4 a$. & $0-15$ & 102 & 30 & 18 & 0.8 & 25.8 & 3.1 & 8.0 \\
\hline $4 b \ldots \ldots$ & $15-35$ & 105 & 26 & 17 & 2.4 & 20.6 & 11.6 & 8.0 \\
\hline $5 \mathrm{a} \ldots$ & $0-20$ & 100 & 14 & 9.6 & 5.6 & 28.0 & 20.0 & 8.8 \\
\hline $5 b \ldots$ & $20-40$ & 150 & 25 & 19 & 3.6 & 20.4 & 17.6 & 8.2 \\
\hline $6 \ldots$ & $0-20$ & 36 & 10 & 7 & 2.8 & 33.0 & 8.5 & 8.35 \\
\hline $7 \ldots \ldots$ & $0-20$ & 840 & 68 & 120 & -5.6 & $\ldots$ & 0.0 & 8.4 \\
\hline $8 \ldots$. & $0-20$ & 1,100 & 70 & 140 & -5.6 & $\ldots$ & 0.0 & 8.5 \\
\hline $9 \ldots$ & $0-20$ & 260 & 54 & 36 & -0.4 & $\ldots$ & 0.0 & 8.1 \\
\hline $10 \ldots \ldots$ & $0-20$ & 1,020 & 74 & 140 & -12.4 & $\ldots$ & 0.0 & 8.5 \\
\hline $11 . \ldots \ldots$ & $\mathrm{C}-20$ & 800 & 49 & 92 & -0.4 & $\ldots$ & 0.0 & 9.0 \\
\hline
\end{tabular}

* 1. At water table, depth $18 \mathrm{~J} \mathrm{~cm}$ in horse bean field.

2. Virgin land.

3. Good potato land.

4. Poor area in potato field.

5. Poor cotton; dense structure.

6. Good cotton.

7. Surface prepared for leaching.

8. Around roots of Saueda fructicora.

9-11. Additional surface crusts. 
in which cotton had made a very poor growth. Results of analyses are shown in table 9 .

The soil of the other delta area, H (fig. 2), is also the tough clay similar to the suspended matter in the Nile at flood time. This farm is typical of a large area west of Damanhour, of low productivity, and shows much evidence of alkali. The water table is not high. The clay and clay loam horizons were underlain by a sandy layer at depths varying from less than one-half meter to more than a meter. The soil appeared similar to the Holtville series found in California. Production was better where the sandy layer was nearer the surface. This area is not believed to have been part of a lake, but an intermittent swamp may have existed here. Results of analyses are shown in table 10 .

\section{Soils Partly of Desert Origin}

In large areas of Egypt, there is either a thin layer of Nile sediment on top of sandy material of desert origin, or the two types of soil material are intermingled. These areas are subject to high water tables since seepage from canals is rapid in the sandier materials.

The first such area visited was at el Tell el Kebir in Wadi Tumilot. A relatively thin layer of Nile silt had been deposited by the ancient Pelusium branch of the Nile. The area has been served by the Ismailia Canal for about 60 years, and there has been much seepage from the canal. The government farm contains 20,000 feddans, of which 6,000 have an alkali problem. Samples were taken in the government farm, Area I (fig. 2). Results of analyses are shown in table 11.

The land in Area J (fig. 2) is located in a depression between the desert and the delta proper. The presence of shells indicates the probable existence of a lake at one time. The low lying land has been subject to seepage for centuries since canals have served the area for at least 600 years.

There is much virgin land showing evidence of high salinity, some on which reclamation has just begun, and some which has reached a stage of high productivity. Results of analyses are shown in table 12.

\section{RESULTS OF THE SOIL SURVEY}

This survey of saline and alkali soils in various parts of Egypt is by no means exhaustive, and is best described as a brief reconnaissance survey to develop some information about a number of typical situations.

In classifying soils with respect to salinity and alkali it is convenient to divide them into four classes as follows:

1. Normal soils. Productive for most crops if physical condition and fertility are satisfactory.

a. Estimated cations in saturation extract should be below 20 m.e./liter.

b. G.R. should be small, 1 or 2 m.e./100 gm for silt or clay soils, and nearly zero for sands. Some productive soils would show a small negative G.R., 1 or 2 m.e. 100 gm.

c. Estimated Ex Na percentages should be below 10 .

2. Saline soils. Production would be reduced because of high total salt content. 
a. Estimated soluble cation concentration in saturation extract above 20 m.e./liter. Concentrations need to be interpreted on the basis of local experience on the tolerance of crops.

b. G. R. nearly zero, and in soils with high salinity often showing a high negative value.

c. Estimated Ex Na percentages should be less than 10 and often zero.

d. Soluble magnesium may greatly exceed calcium because of the low solubility of calcium in the presence of sulfate ions.

3. Alkali soils. Productivity may be impaired because of dispersed condition or the toxic effect of absorbed $\mathrm{Na}$.

a. Estimated concentration of soluble cations in saturation extract is so low that impaired production cannot be ascribed to salinity.

b. G.R. will be high. Estimated Ex Na percentages would be expected to exceed 10, and in the worst cases would exceed 50.

4. Saline-alkali soils. Unproductive soils containing excessive quantities of soluble salts and also a substantial proportion of Ex $\mathrm{Na}$.

a. Sodium is the predominant soluble cation, that is, soluble calcium and magnesium percentages will be low in contrast to the situation in Class 2.

b. G.R. and estimated Ex Na percentage values will be high.

All of these classes of soils were encountered in this reconnaissance survey. One hundred three soil samples were analyzed with results shown in tables 3 through 12 . Only seven of these samples could be described as normal. Normal soil was encountered in horizons below the surface 20 to $25 \mathrm{~cm}$ in only one location, number 1, Area F (table 8). Eleven samples could be described as nearly normal and could probably be reclaimed by moderate leaching with Nile water. Thirty-six samples would be placed in Class 2, saline soils with adequate supplies of calcium and magnesium. Such soils were found at all areas except $\mathrm{F}$ (table 8), and $\mathrm{H}$ (table 10). Twenty-one samples would be placed in Class 3, nonsaline alkali soils. Such soils were encountered in three of the five locations in the northern lake region (tables 3,5, and 6), and included seven out of the 10 samples from Area $\mathrm{H}$ (table 10). Three of the seven samples from Area I (table 11) were in Class 3. Twenty-four samples were in Class 4 , which was found in all areas except $\mathrm{C}$ and $\mathrm{E}$ (tables 5 and 7 ).

With the possible exception of three samples (table $3,3 \mathrm{~b}$ and $6 \mathrm{~b}$, and table $5,1 \mathrm{~b})$, no evidence was found indicating the presence of high magnesium soils, as suggested by Gracie et al. (1934). All of the samples were calcareous.

It is not hard to understand the presence of all these types of saline and alkali soils, but it is difficult to explain the intermingling of classes.

The general rule in the soil of the lakes region is that saline crusts are high in calcium and magnesium. $\mathrm{Ex} \mathrm{Na}$ is estimated to be nil in surface soils. There is, however, a rapid increase in the estimated Ex Na percentage with increasing depth. The reverse of this situation, however, is found at el Sirw (table 7), where there is a low G.R. in the surface $50 \mathrm{~cm}$, and the horizon from 50 to $75 \mathrm{~cm}$ is gypsiferous.

There appears to be no good correlation between the nature of the soil and the present depth of the water table. One of the most amazing things 
is the excellent growth of crops on some of the heavy-textured soils with water tables only 50 to $60 \mathrm{~cm}$ from the surface. The worst alkali soils were encountered in Area $\mathrm{H}$ (table 10), and samples $4 \mathrm{a}$ and $\mathrm{b}$ from Area I (table 11).

Another striking phenomenon is the absence of any laboratory or field evidence of "black alkali" in the sense of a soil darkened by dissolved organic matter. Almost all of the soils examined produced water-white extracts; only a few gave extracts of a pale straw color. Even in the cases just noted, where exchangeable sodium percentages and $\mathrm{pH}$ 's were high, the extracts were not colored. Nowhere on extensive field trips throughout Egypt was evidence observed of soils colored by soluble organic matter, or of the darkcolored drainage water so often seen in California.

It is possible that black color is absent because the organic matter content is either low or unusually resistant both to decay and solution. Boiling some of the alkali soil from Area $\mathrm{H}$ in normal sodium hydroxide produced a pale brown solution. Boiling some normal delta soil in the same manner produced a solution much more deeply colored. Cold, normal sodium hydroxide did not produce a colored extract with either soil.

Representative soil samples were sent from Egypt to the Agricultural Extension Soils Laboratory in Berkeley for determination of organic matter. The results are shown in table 13. The organic matter content of these soils, both normal and alkali, is very low in relation to the C.E.C. The single exception is the alkali soil from Area I. A swampy condition at this location would account for the high organic content. Even though the estimated exchangeable sodium percentage was about 60 , this soil did not produce a dark-colored extract. Reports of the occurrence of black alkali may be the result of the presence of calcium chloride in the salt crusts. This salt is deliquescent, and the absorption of moisture causes the soil to appear black. Such a condition was observed in many places in Egypt, and has also been observed in the Imperial Valley of California. The analyses in tables 3 through 12 indicate the presence of calcium chloride since, in many cases, the amount of soluble calcium found greatly exceeds the solubility of calcium sulfate.

It seemed strange that an absolutely barren soil should be found within 8 feet of one producing an excellent crop of berseem at Area F (table 8). The values for C.E.C. revealed a possible explanation. Where the crop was good, the surface C.E.C. was 39 m.e. $/ 100 \mathrm{gm}$, and in the horizon just above the water table the C.E.C. was 33.5 m.e. $/ 100 \mathrm{gm}$. The respective values for the barren saline-alkali soil were 29 and 33 . The lower value in the surface soil indicated a coarser texture which would permit a more rapid rise of water from the water table at $50 \mathrm{~cm}$ and a rapid accumulation of alkalizing sodium salts.

The results of this survey do not indicate that a water such as that of the Nile is necessarily an alkalizing water. There is an intermingling of the saline and alkali soils much like the situation in California. The salinization and alkalization seem to be associated with high water tables or poor permeability.

One custom prevalent in the country is an attempt to remove surface 
accumulations of salt by flushing. This is difficult to do and in most cases would be unwise even if possible. As indicated above, these crusts are often high in calcium and magnesium salts.

A small experiment was conducted with soils from Area A (table 3). A small lot of sample 1a, the very saline surface crust, was leached with distilled water until nearly salt-free. This soil, which had shown a negative G.R. of $24 \mathrm{~m} . \mathrm{e} . / 100 \mathrm{gm}$, showed a small positive G.R. of $2 \mathrm{~m} . e . / 100 \mathrm{gm}$ after leaching. The leachate from 1 was passed through soil $1 \mathrm{~b}$. This resulted in a G.R. of 5.6 m.e./100 gm compared with 8.4 in a lot of $1 \mathrm{~b}$ leached with

TABLE 13

ORGANIC MATTER AND CATION EXCHANGE CAPACITIES

OF SOME EGYPTIAN SOILS

\begin{tabular}{|c|c|c|}
\hline Soil description & $\begin{array}{c}\text { Total organic } \\
\text { matter }\end{array}$ & C.E.C. \\
\hline & per cent & $m . e . / 100 \mathrm{gm}$ \\
\hline Nile silt from main canal.. & 2.2 & 52 \\
\hline 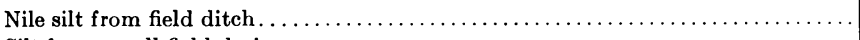 & 2.9 & 53 \\
\hline 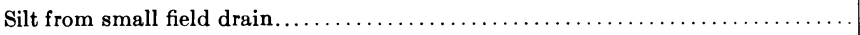 & 1.4 & 48 \\
\hline 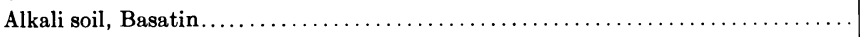 & 1.1 & 42 \\
\hline Good soil, Basatin................ & 2.2 & 40 \\
\hline Alkali soil, el Tell el Kebir, surface.... & 4.3 & 37 \\
\hline Alkali soil, el Tell el Kebir, subsoil.... & 1.4 & 44 \\
\hline Alkali soil, Abou Youssef, $0-35 \mathrm{~cm} \ldots \ldots \ldots$ & 1.2 & 42 \\
\hline Alkali soil, Abou Youssef, $35-85 \mathrm{~cm} . . . \ldots$ & 0.9 & 37 \\
\hline Alkali soil, Abou Youssef, $85-100 \mathrm{~cm} . \ldots \ldots$. & 1.1 & 51 \\
\hline Alkali soil, U. of Alex. farm, 0-25 $\mathrm{cm} \ldots \ldots$. & 0.5 & 16 \\
\hline Alkali soil, U. of Alex. farm, $25-50 \mathrm{~cm} \ldots \ldots$ & 0.6 & 32 \\
\hline 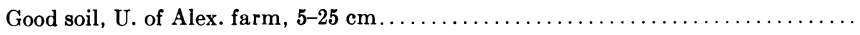 & 0.8 & 37 \\
\hline 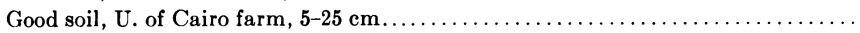 & 1.8 & 40 \\
\hline
\end{tabular}

distilled water only. The saline leachate from $1 \mathrm{a}$ and $1 \mathrm{~b}$ was in turn passed through a lot of soil 1c. The G.R. was 8.0 m.e./100 gm, as compared with 11.2 in a lot leached with distilled water only. This experiment indicated that the excess soluble calcium and magnesium in the surface $5 \mathrm{~cm}$ had a value equivalent to 6.8 metric tons of gypsum per feddan for replacing sodium in the subsurface horizons. (A G.R. of 1 m.e./100 gm represents 1 metric ton per feddan for a depth of $20 \mathrm{~cm}$.) The determined negative G.R. of $24 \mathrm{~m} . e . / 100 \mathrm{gm}$ in the surface $5 \mathrm{~cm}$ has a calculated gypsum value of 6 metric tons per feddan, which is in close agreement with the experimental results. A 1:20 water extract was made on sample 1a to see if an increase in calcium above that found in the saturation extract would indicate the presence of gypsum. Very little gypsum was found, indicating that most of the soluble calcium was associated with chloride.

\section{RECLAMATION EXPERIMENTS BY POT TESTS}

The principles of reclamation include good drainage, leaching with a suitable irrigation water, usually the addition of soil amendments to change the chemical nature of the soil, and, finally, good farming methods. Reclamation processes may be slow. Therefore, persistence and patience on the part of the operator are essential. 
Despite our knowledge of the chemical nature of soils and of soil management principles, reclamation is essentially an art. This art has been practiced most successfully on sandy and sandy loam soils. Reclamation of fine-textured soil presents many difficulties, and much field experimentation is often required to develop suitable methods for particular situations. Overstreet, Martin, and King (1951) have shown that pilot experiments conducted in large-sized pots may serve as a reliable guide to the formulation of reclamation procedures and thus lessen the need for extensive field experiments.

Before planting. A pot-culture experiment was therefore conducted with a fine-textured alkali soil of moderate salinity. The soil chosen was from Area $\mathrm{H}$ (fig. 2) at a spot near location 3 (table 10). One thousand pounds of soil, representing the surface $20 \mathrm{~cm}$, were taken to the College of Agriculture at Alexandria for this study. This soil appears similar in texture and general morphological characteristics to a soil of the Holtville series found near Ripley in the Palo Verde Valley of California. The California soil has proved very difficult to reclaim.

The entire sample was air dried, ground to pass a sieve with 2-millimeter, round holes, and thoroughly mixed. Its characteristics are indicated by the following analysis:

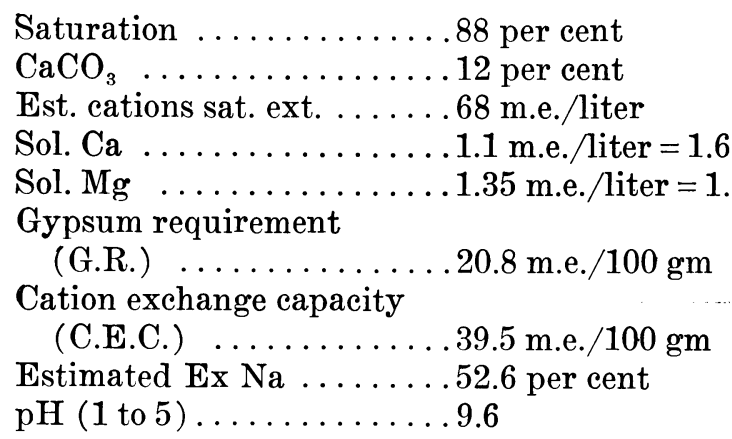

An X-ray examination indicated that the clay mineral in this soil is principally montmorilonite; some kaolinite is also present. Five-gram lots of the soil were leached with $100 \mathrm{ml}$ of normal $\mathrm{NaCl}$, and the so-called "extractable" calcium and magnesium were determined. Calcium amounted to 9.0 m.e. $/ 100 \mathrm{gm}$, and magnesium $5.7 \mathrm{~m} . e . / 100 \mathrm{gm}$. Since the sum of the soluble calcium and magnesium is only 0.2 m.e. $/ 100 \mathrm{gm}$, they may be neglected. According to Bower (1952), this amount of leaching with normal $\mathrm{NaCl}$ would be unlikely to remove all the exchangeable calcium ( $\mathrm{Ex} \mathrm{Ca}$ ) and magnesium but would dissolve some calcium from $\mathrm{CaCO}_{3}$ which would be counted as Ex Ca. If the G.R. may be taken as a close estimate of the Ex Na, the sum of the determined and estimated cations was 35.5, or 90 per cent of the C.E.C.

An experiment was planned in which pots of this soil were to be treated with gypsum and with $\mathrm{H}_{2} \mathrm{SO}_{4}$ both at rates believed to be adequate for full reclamation and at 50 per cent of those rates. The soil was placed in enameled metal containers of a type designed for Mitscherlich experiments. Subcontainers were provided for collecting leachates. Drainage was provided in 
the bottom of each pot by means of a large hole covered with a metal disk, some glass wool, a 25 -cm filter paper, and a thin layer of acid-washed sand. A total of $14.5 \mathrm{~kg}$ of the soil was placed in each pot. On the basis of the analyses reported, each pot contained an estimated 3,050 milliequivalents of $\mathrm{Ex} \mathrm{Na}$ and an estimated 840 m.e. of mixed soluble salts, 96 to $97 \mathrm{per}$ cent of which consisted of sodium salts.

Since, in a leaching experiment, the soluble calcium will not be utilized with 100 per cent efficiency in replacing $\mathrm{Ex} \mathrm{Na}$, it is necessary to apply more gypsum than the determined amount of 20.8 m.e. $/ 100 \mathrm{gm}$. It was planned to make the full treatment at the rate of 22.5 m.e. $/ 100 \mathrm{gm}$, and calcium sulfate was applied on this basis. Subsequent analyses indicated that the calcium sulfate used was partially dehydrated, so that the full treatment amounted to 26.2 m.e. $/ 100 \mathrm{gm}$, or an excess over the G.R. of 25 per cent. Concentrated $\mathrm{H}_{2} \mathrm{SO}_{4}$ (concentration verified by analysis) was applied in equivalent amounts.

Three liters of tap water were added to each pot on January 23, 1954. The time required for this amount of water to soak completely into the soil was as follows:

$\begin{array}{cc}\text { Pot no. } & \text { Average time (minutes) } \\ 1,2,13 & \text { (Water still standing on surface after one month) } \\ 3,4 & 76 \\ 5,6 & 41 \\ 7,8 & 52 \\ 9,10 & 61 \\ 11,12 & 52\end{array}$

Pots 1, 2, and 13 were covered to prevent evaporation, but at the end of the month the covers were removed and the water was allowed to evaporate. On drying, the soil cracked and flaked up in badly dispersed flakes about $1 / 4$-inch thick.

After drying for two days, all the pots except those in treatment A developed distinetive soil structure patterns as shown in figure 3. On January 26, 3 more liters of tap water were added to each pot except treatment A, and on January 28, 2 additional liters. The water-holding capacity (field capacity) of a $14.5-\mathrm{kg}$ lot of soil was estimated at 5 liters. More than this would have to be added to saturate part of the soil and start leaching. As a matter of fact, drainage did not start until 10 liters had been added, or enough to saturate all of the soil.

A 2-liter increment added on January 28 produced some leachate in all treatments except A and B. Treatment A produced no leachate at any time during the experiment. Leaching was continued until March 9 when the soils were considered ready for planting.

An excellent structure developed in all treatments except A and B. The initial high permeability was not maintained, however. There was a gradual slowdown to a point where 24 hours were required for 3 liters of water to soak into treatments $\mathrm{D}$ and $\mathrm{F}$, and for 2 liters to soak into treatment $\mathrm{B}$. The permeability remained best in treatment C, and was nearly as good in E. The soil in the gypsum-on-top treatment, B, swelled to the extent that 

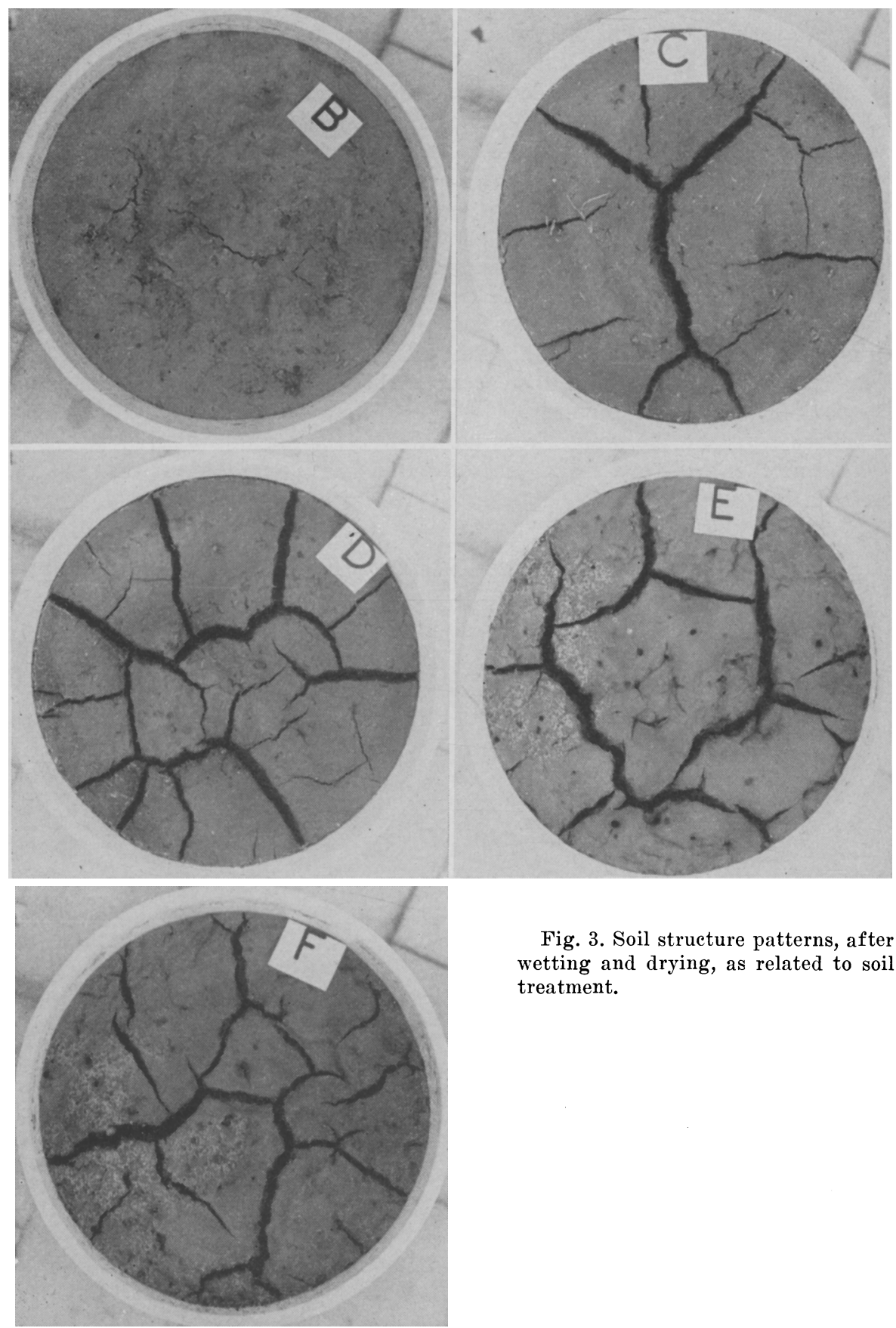

Fig. 3. Soil structure patterns, after wetting and drying, as related to soil treatment. 
the distance from the soil surface to the top rim of the container was reduced from 6 or $7 \mathrm{~cm}$ to 3 . A bad surface crust also formed, and was broken up by light cultivation. The $\mathrm{H}_{2} \mathrm{SO}_{4}$ dissolved all of the $\mathrm{CaCO}_{3}$ in the top 6 or $7 \mathrm{~cm}$ of soil, converting it to gypsum. The $\mathrm{pH}$ of the surface layer was reduced to 4 in treatment $\mathrm{E}$, and 5.7 in $\mathrm{F}$.

TABLE 14

ANALYSES OF LEACHATES BEFORE PLANTING

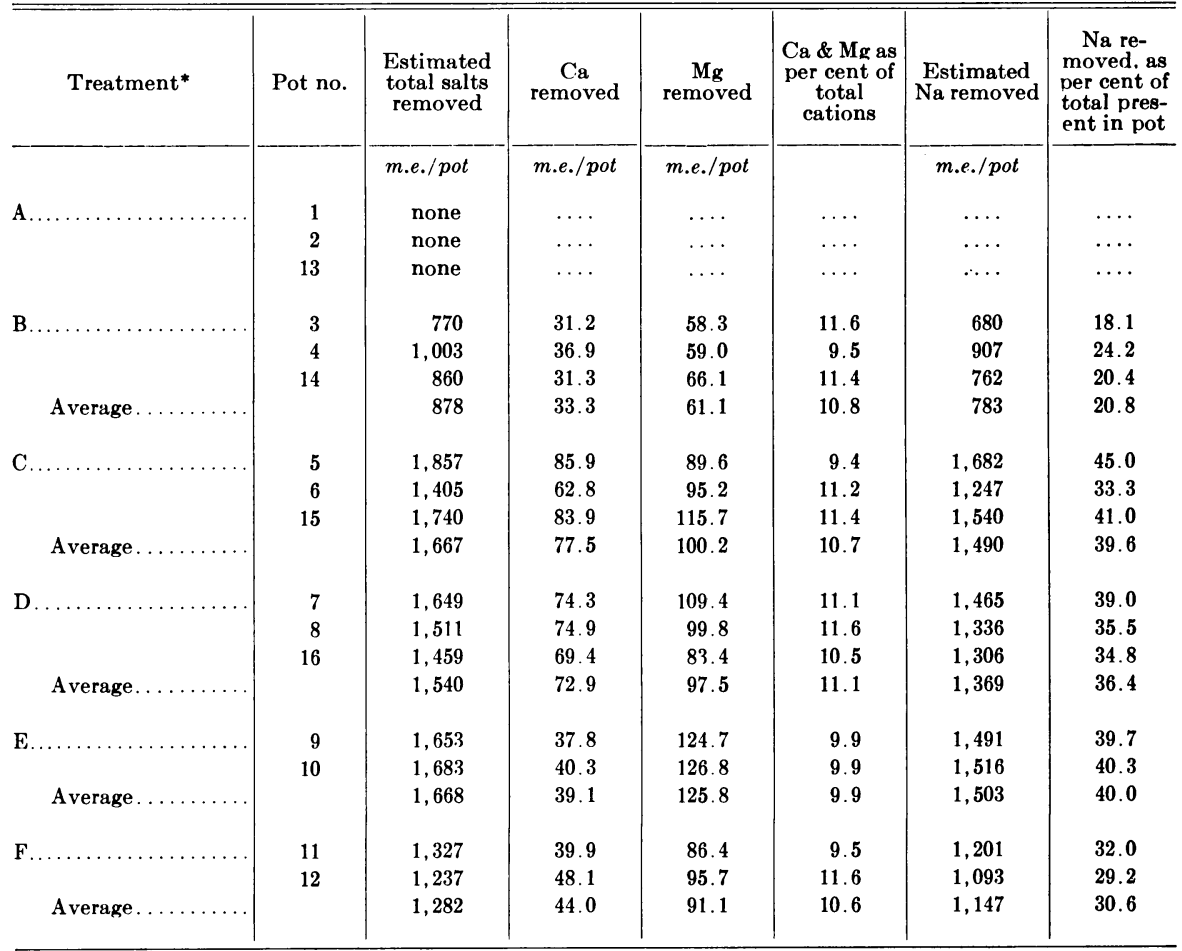

* A. Soil plus tap water only.

B. Soil plus $282 \mathrm{gm} \mathrm{CaSO}_{4}=3,800 \mathrm{~m}$.e. $\mathrm{Ca} /$ pot, mixed with top $1 \mathrm{~cm}$ of soil.

C. Soil plus $282 \mathrm{gm} \mathrm{CaSO}$, mixed with soil in top half of pot-about $15 \mathrm{~cm}$.

D. Soil plus $141 \mathrm{gm} \mathrm{CaSO} 4=1,900 \mathrm{~m}$.e. Ca/pot, mixed with top half of soil.

E. Soil plus $192 \mathrm{gm} 98 \% \mathrm{H}_{2} \mathrm{SO}_{4}=3,840 \mathrm{~m} . \mathrm{e} . / \mathrm{pot}$, dripped on top of soil.

F. Soil plus $96 \mathrm{gm} 98 \% \mathrm{H}_{2} \mathrm{SO}_{4}=1,920 \mathrm{~m} . \mathrm{e} . /$ pot, dripped on top of soil.

During the period from January 31 to March 9, five leachates were collected. (Treatment A gave none, and B produced three in pots 3 and 14, and four in pot 4.) All of these leachates were analyzed for electrical conductance, calcium, and calcium plus magnesium by versenate titration. The combined results obtained from the leachates before planting are shown in table 14.

The data in table 14 indicate several conclusions:

1. Gypsum mixed with soil was twice as effective in facilitating removal of sodium as was gypsum on top.

2. Sulfuric acid, full treatment, had about the same efficiency as gypsum, full treatment, mixed with soil. 
3. Sulfuric acid, half treatment, was less efficient than gypsum, half treatment, mixed with soil. Permeability differences confirmed this. Perhaps this result was obtained because the $\mathrm{H}_{2} \mathrm{SO}_{4}$ influenced a thinner layer of soil.

4. During the 40-day period, only 40 per cent of the total $\mathrm{Ex}+\mathrm{Sol}$. Na was removed in the most efficient treatments even though, in the case of gypsum, the material was mixed with one half of the soil.

5 . The half-rate treatment with gypsum was almost as efficient as the full rate since it supplied enough calcium to replace the sodium in the soil with which it was mixed.

6. The removal of the remaining sodium would appear to be a slow process, depending upon the slow solubility of gypsum.

7. The soluble calcium and magnesium apparently replaced sodium with great efficiency since losses of the divalent cations were only about 11 per cent.

8. The $\mathrm{H}_{2} \mathrm{SO}_{4}$ treatments removed somewhat less calcium and somewhat more magnesium than did the gypsum treatments, but the total of the divalent cations was only slightly less.

After planting. Pots 1 through 12 were planted to barley, and 13 through 16 to Vicia faba (horse beans) on March 16. The barley germinated on March 20, and the horse beans on March 23. Barley pots were fertilized with $\mathrm{NH}_{4} \mathrm{NO}_{3}$ to supply nitrogen at the rate of 100 pounds per acre. Growth was rapid. Photographs taken on the 21st day are shown in figure 4 , and those taken on the 53d day in figure 5. Barley was nearly mature on May 23, and all pots, including the still green horse beans, were harvested on that date. Dry weights of the plants, grain, and straw are shown in table 15.

During the total period of cropping, water was applied as needed, and leachates were allowed to accumulate in the containers, from which they were collected for analysis. The combined analyses of the leachates collected during this period are shown in table 16 .

It is surprising that some barley grew in the check pots, treatment A, which received tap water only. The permeability was so poor that the pots were never wet to the bottom. The barley plants showed little so-called salt injury or scorch, but were depressed in growth and looked like plants suffering from drought even though they were watered every day. Germination of the barley was slow, in treatment A, and of horse beans, practically nil.

It is evident from the data and the photographs that all of the soil amendment treatments promoted good growth of barley and horse beans. The treated pots were significantly better than the untreated, but the difference between treatments was of doubtful significance.

The barley (horse beans in four containers) was followed by cotton planted June 6 and harvested August 30. The yield of entire plants, in grams per pot, dry-weight, is shown in table 17. As in the case of the barley, the yield in treatment A was surprisingly good even though it was less than half that obtained in the other treatments. Here again, all of the amendment treatments promoted a good growth of cotton and the difference between the treatments was barely significant. There was considerable growth stimulation in the pots having a previous crop of horse beans. 
Soil samples representative of the top half of the soil in each pot were taken following the cotton harvest. These were analyzed with results as shown in table 18.

\section{RESULTS OF POT TESTS}

The pot experiment furnished much valuable information about the particular soil used in the tests-fine-textured, alkali, of high Ex Na percentage but moderate salinity. Water alone promoted fair growth of both barley

TABLE 15

YIELD OF BARLEY AND HORSE BEANS-TOTAL DRY'WEIGHT

\begin{tabular}{|c|c|c|c|c|}
\hline \multirow{2}{*}{ Treatment } & \multirow{2}{*}{ Pot no. } & \multicolumn{2}{|c|}{ Yield } & \multirow{2}{*}{$\begin{array}{c}\text { Average of } \\
\text { treatment, } \\
\text { barley }\end{array}$} \\
\hline & & Barley & Horse beans & \\
\hline A. Soil and tap water only & $\begin{array}{r}1 \\
2 \\
13\end{array}$ & $\begin{array}{c}g m / p o t \\
24.2 \\
24.8 \\
\ldots\end{array}$ & $\begin{array}{c}g m / p o t \\
\ldots \\
1.32 \\
\ldots\end{array}$ & $\begin{array}{c}g m / p o t \\
24.7\end{array}$ \\
\hline B. Same plus gypsum on top & $\begin{array}{r}3 \\
4 \\
14\end{array}$ & $\begin{array}{l}62.4 \\
62.2 \\
\ldots .\end{array}$ & $\begin{array}{c}\ldots \ldots \\
\ldots \ldots \\
178.5\end{array}$ & 62.3 \\
\hline C. Same but gypsum mixed with soil & $\begin{array}{r}5 \\
6 \\
15\end{array}$ & $\begin{array}{l}73 \\
61 \\
\ldots\end{array}$ & $\begin{array}{c}\ldots \ldots \\
\ldots \ldots \\
198.9\end{array}$ & 67 \\
\hline D. Same but gypsum at $1 / 2$ rate & $\begin{array}{r}7 \\
8 \\
16\end{array}$ & $\begin{array}{l}60.8 \\
67.3 \\
\ldots .\end{array}$ & $\begin{array}{c}\ldots \ldots \\
\ldots \ldots \\
158.6\end{array}$ & 64 \\
\hline E. Soil plus tap water plus $\mathrm{H}_{2} \mathrm{SO}_{4}$ & $\begin{array}{r}9 \\
10\end{array}$ & $\begin{array}{l}82.5 \\
75.3\end{array}$ & $\begin{array}{l}\ldots \\
\ldots\end{array}$ & 78.9 \\
\hline F. Same as $\mathrm{E}$, but $\mathrm{H}_{2} \mathrm{SO}_{4}$ at $1 / 2$ rate & $\begin{array}{l}11 \\
12\end{array}$ & $\begin{array}{l}64.8 \\
64.8\end{array}$ & $\begin{array}{l}\ldots . \\
\ldots \ldots\end{array}$ & 64.8 \\
\hline
\end{tabular}

LSD $5 \%$ level, \pm 11.88 .

LSD $1 \%$ level, \pm 18.6 .

and cotton in cultures of this kind which could be watered every day. Both of these plants tolerated the Ex $\mathrm{Na}$, but the horse beans did not, and failed to grow. Better control of soil moisture permitted better plant growth in the pots than in the field. The frequent application of water in the pots tended to reduce the salinity in the surface soil even in treatment A where no leaching took place at any time. This is evident from the soil analyses for pots 1, 2, and 13 (table 18). The salinity of the surface soil had been reduced below half of its initial value. Similar effects in such containers have been observed in California (unpublished data).

The results are especially interesting with respect to the $\mathrm{Ex} \mathrm{Na}$ relationships in the various treatments. Water alone, even though relatively high in calcium and magnesium, had little influence on the $\mathrm{Ex} \mathrm{Na}$, as indicated by the high G.R.'s in the soil fom pots 1, 2, and 13 (table 18). The Ex Na 


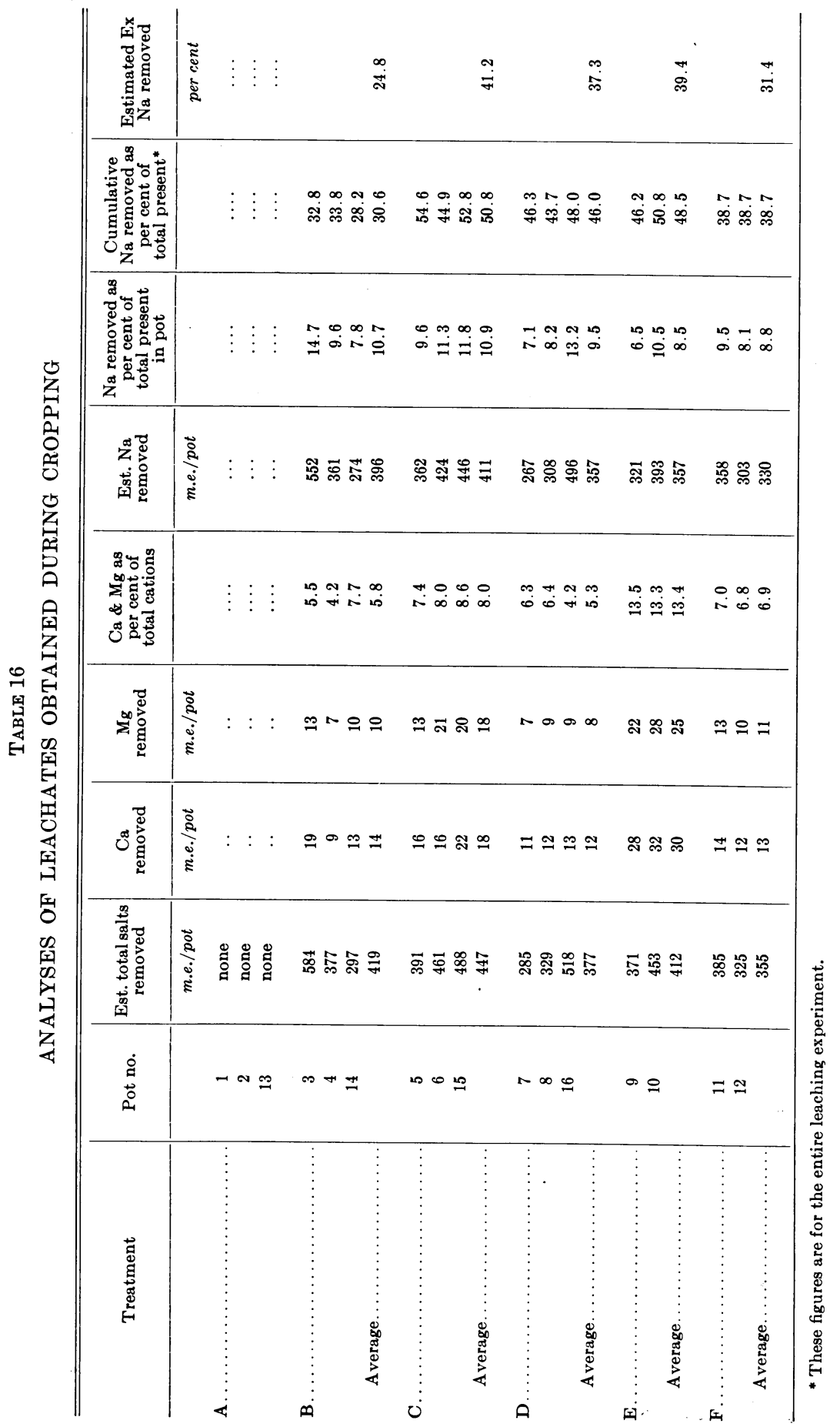




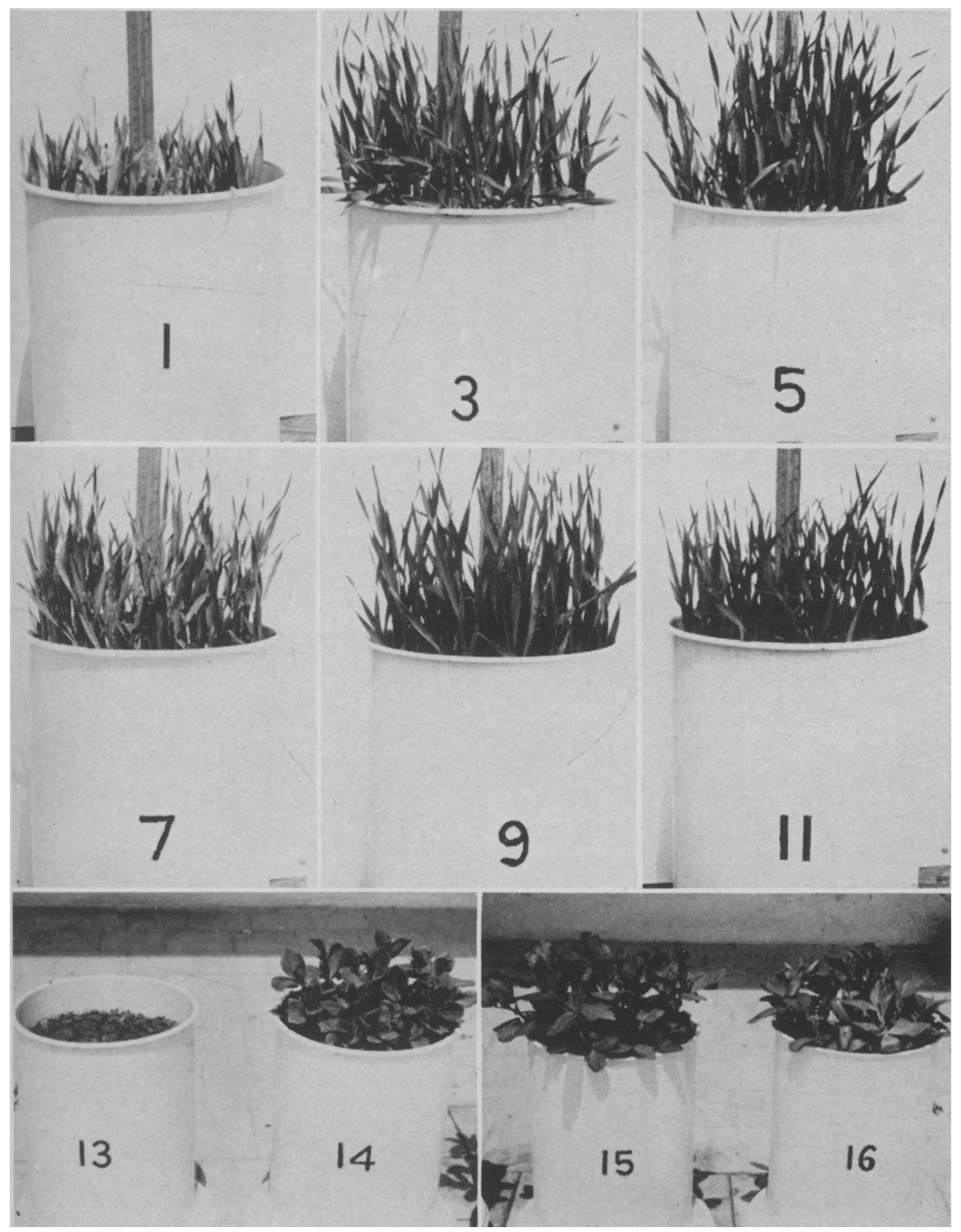

Fig. 4. Barley and horse beans 21 days after planting. 


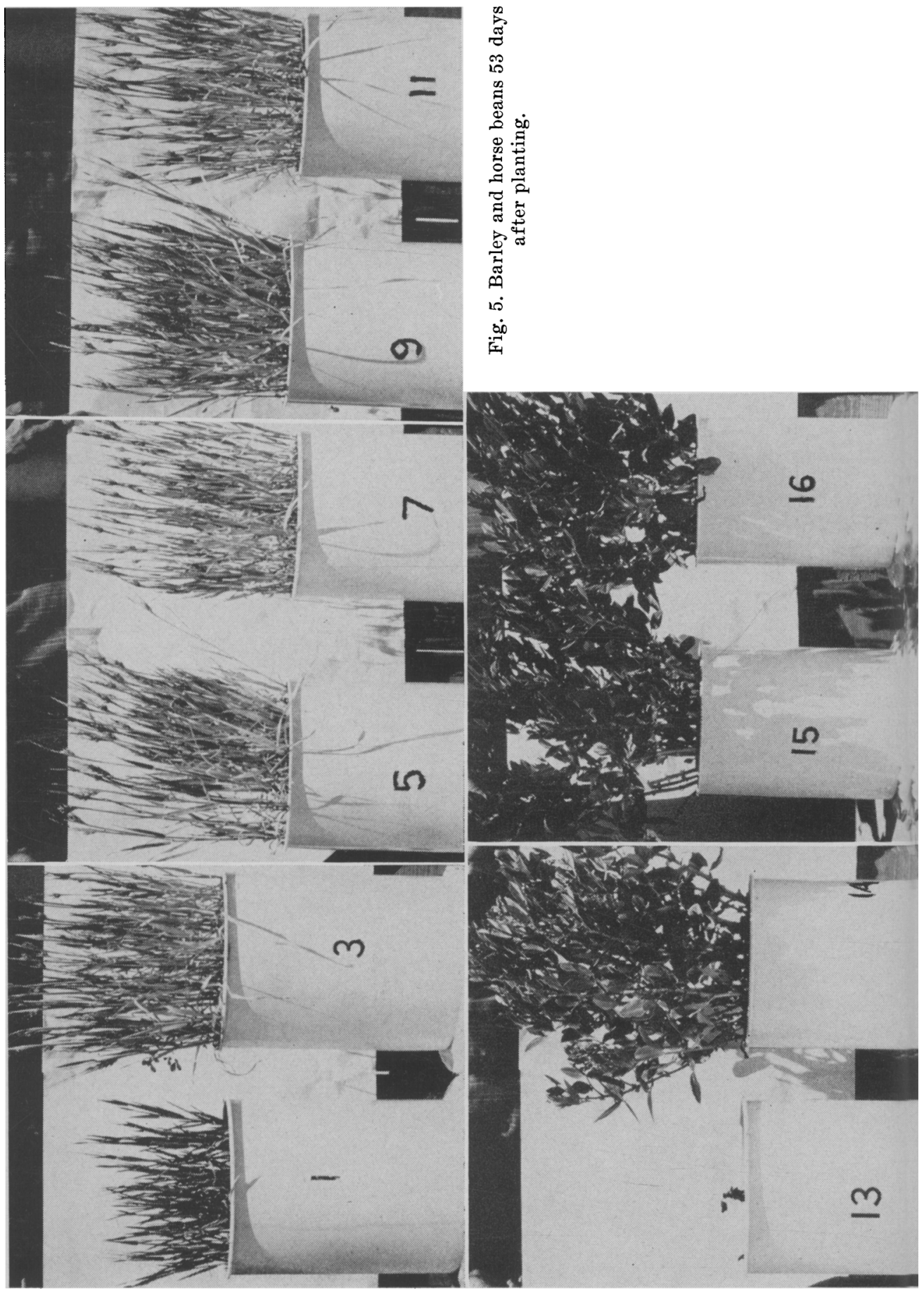


was reduced to satisfactorily low levels in the top half of each of the other treatments regardless of material, treatment rate, or method of application. The chemical data in table 16 show some interesting differences, however, in the apparent removal of $\mathrm{Ex} \mathrm{Na}$ from the soil throughout the containers.

The treatments may be rated as follows in the efficiency of removal of $\mathrm{Ex} \mathrm{Na}$ :

\section{Treatment \\ Ex Na removal (per cent)}

C. Gypsum, full rate, mixed with top half of soil...... 41.2

E. Sulfuric acid, full rate, dripped on soil........... 39.4

D. Gypsum, half rate, mixed with top half of soil...... 37.3

F. Sulfuric acid, half rate, dripped on soil.......... 31.4

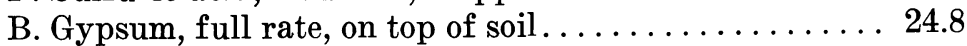

A. Water only $\ldots \ldots \ldots \ldots \ldots \ldots \ldots \ldots \ldots \ldots \ldots \ldots \ldots \ldots, 0.0$

It thus appears that mixing gypsum with the soil facilitates removal of Ex $\mathrm{Na}$ from at least the layer with which it is mixed. However, any treatment which improved permeability and permitted removal of most of the soluble salt resulted in reasonably good production of the three crops even though there was great variability in the removal of Ex Na.

TABLE 17

YIELD OF COTTON PLANTS-DRY WEIGHT

\begin{tabular}{|c|c|c|c|}
\hline Pot no. & $\begin{array}{l}\text { Treatment and } \\
\text { previous crop }\end{array}$ & Yield & $\begin{array}{l}\text { Average of pots } \\
\text { preceded by } \\
\text { barley }\end{array}$ \\
\hline & & $g m / p o t$ & $g m / p o t$ \\
\hline 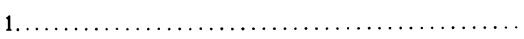 & A - Barley & 11.4 & \\
\hline 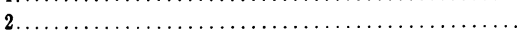 & Barley & 14.8 & 13.1 \\
\hline 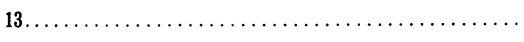 & Horse beans & 17.4 & \\
\hline 3. & B - Barley & 26.9 & \\
\hline$\ldots \ldots \ldots$ & Barley & 27.1 & 27.0 \\
\hline $14 \ldots \ldots \ldots \ldots \ldots \ldots$ & Horse beans & 33.4 & \\
\hline 5.. & C-Barley & 31.4 & \\
\hline$\ldots \ldots \ldots \ldots \ldots \ldots$ & Barley & 32.4 & 31.9 \\
\hline (n. & Horse beans & 38.9 & \\
\hline$\ldots \ldots \ldots \ldots \ldots \ldots$ & D-Barley & 30.4 & \\
\hline $8 \ldots \ldots \ldots \ldots \ldots \ldots$ & Barley & 29.4 & 29.9 \\
\hline 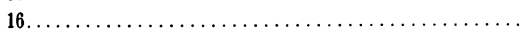 & Horse beans & 34.4 & \\
\hline $9 \ldots \ldots \ldots \ldots \ldots \ldots$ & E - Barley & 27.8 & \\
\hline 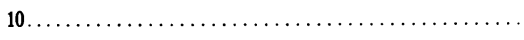 & Barley & 27.2 & 27.5 \\
\hline 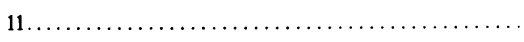 & F - Barley & 28.9 & \\
\hline $12 \ldots \ldots \ldots \ldots \ldots \ldots \ldots \ldots \ldots \ldots \ldots \ldots \ldots \ldots$ & Barley & 26.6 & 27.7 \\
\hline
\end{tabular}

LSD for cotton following barley, $5 \%$ level, 2.2 .
LSD for cotton following barley, $1 \%$ level, 5.6. 


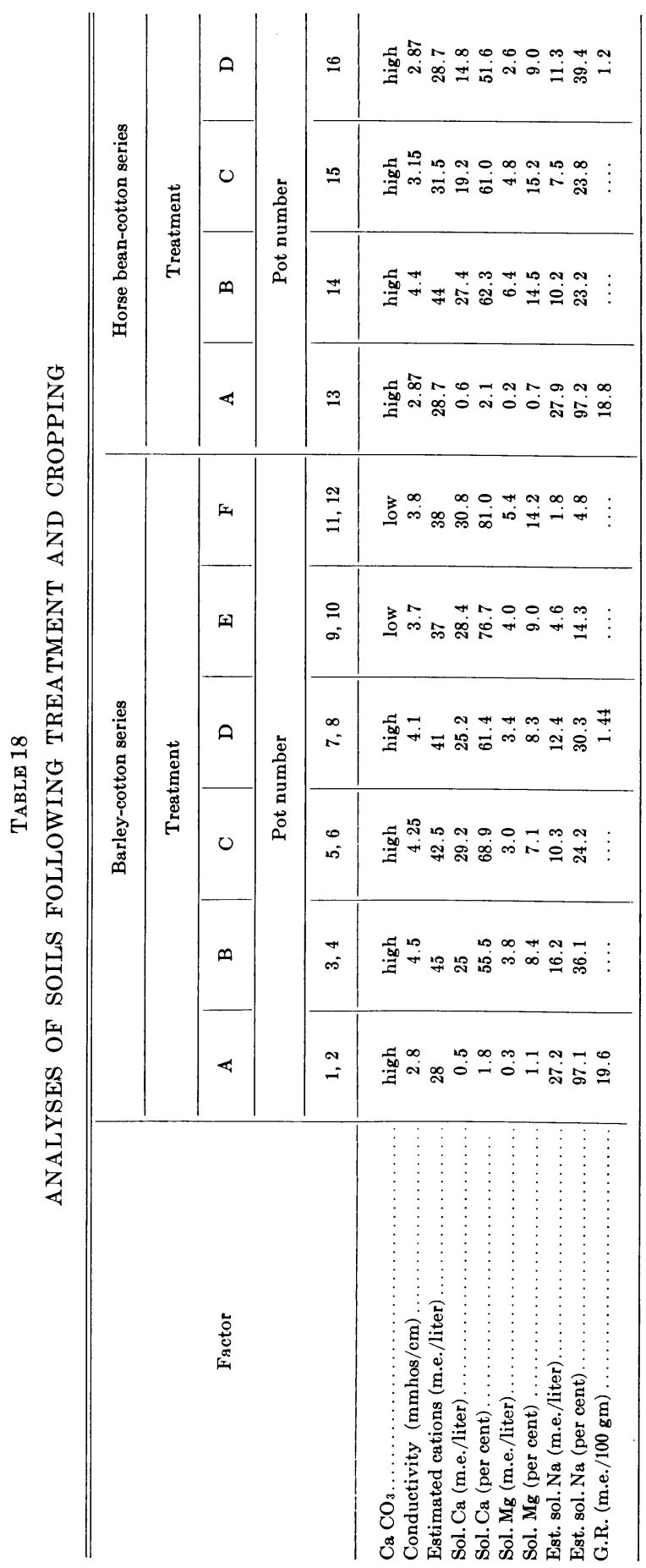




\section{FIELD EXPERIMENTS}

Reclamation experiments were laid out in the same field at Area $\mathrm{H}$ farm (fig. 2) from which the soil was collected for the pot culture experiments. According to samples taken previously, this area had a gypsum requirement of 20 to 24 tons per acre per $20 \mathrm{~cm}$.

Gypsum, 80 per cent pure, was applied to plots $1 / 70$ acre in size at rates of 800 and 400 pounds per plot, or 28 and 14 tons per acre. This is equivalent to 22.5 and 11.25 tons per acre of pure gypsum.

Concentrated sulfuric acid was applied to plots $1 / 2,000$ acre in size at rates equivalent to the gypsum treatments. The amounts applied were 4 and 2 liters per plot.

The gypsum treatments were randomized and replicated eight times. The sulfuric acid treatments were randomized and replicated six times. The gypsum was mixed with the soil by hoeing, and the sulfuric acid was sprinkled on the surface. The plots were then irrigated.

Yield records have not been obtained, and the only results available are observations on water penetration. The plots were irrigated at intervals for about six weeks, after which water was withheld to prepare for planting. Water soaked into all of the treated plots in approximately one and one-half days following a heavy irrigation, remained on the untreated plots for 15 days, and finally evaporated.

\section{SUMMARY AND CONCLUSIONS}

The Nile Valley and delta consist of lands developed and farmed under arid conditions similar to those found in the interior valleys of California. The soils have been irrigated by annual flooding with an excellent water for many centuries, and for 50 years by perennial irrigation with stored water of somewhat lower quality and containing about 1.4 m.e. per liter of residual sodium carbonate.

This survey and the accompanying field observations, while inadequate to permit broad conclusions, show some evidence that the use of Nile water for perennial irrigation has had an alkalizing influence. The saline and alkali soils found in Egypt are similar to those developed under the influence of the Kings River in California, which is also an alkalizing water. The occurrence of soils of high Ex Na content as well as of high salinity was usually associated with high water tables or poor permeability.

The extensive saline areas in the fringe of the delta at or below sea level are capable of reclamation, usually by effective drainage plus leaching. Some portions of these areas contain sufficient Ex Na to make advisable the use of a soil amendment such as gypsum.

The studies indicated that the determination of electrical conductivity of saturation extracts, soluble divalent eations, gypsum requirement, and cation exchange capacity afforded a good appraisal of saline and alkali soils as related to plant growth. These few determinations, made by quick and economical methods, served to classify the soils, explain observed differences in plant growth and in permeability, and to outline reclamation procedures. 
A new and quick method for cation exchange capacity was developed during the study.

The pot-culture study demonstrated that large-sized containers can be used effectively to study the properties of fine-textured, alkali soils, and that such studies are a useful preliminary to field tests of reclamation procedures.

This study in all of its phases indicates that Egypt is a good place in which to study salinity and alkali problems. It has the advantage of a single water supply, and the soils of large areas come from common parent sources.

\section{ACKNOWLEDGMENTS}

Thanks are extended to the U. S. Educational Foundation for Egypt and to the Faculty of Agriculture of the University of Alexandria for providing the funds and facilities which made this study possible.

Much of the analytical work was conducted by graduate students Mohyee el Defrawi and Fathy Massoud of the University of Alexandria. Transportation and other facilities were furnished by the U. S. Technical Coöperation Mission in Cairo. Transportation was also furnished by the Egyptian Ministry of Agriculture and by coöperating farm owners.

For assistance in developing the methods, thanks are due James Quick, Principal Laboratory Technician, Agricultural Extension, Berkeley.

\section{APPENDIX}

\section{Gypsum Requirement Determination}

If an alkali soil is shaken with saturated gypsum solution, an equilibrium reaction takes place in which sodium and magnesium are replaced by calcium. Sodium carbonate also reacts with the gypsum to precipitate $\mathrm{CaCO}_{3}$. If the calcium plus magnesium in the extract is determined by titration, the difference between this value $\left(\mathrm{Ca}^{++}\right.$plus $\left.\mathrm{Mg}^{++}\right)$and the calcium in the standard gypsum solution indicates the amount of calcium removed from the solution to replace sodium (and perhaps some potassium) plus the $\mathrm{Ca}^{++}$ precipitated as $\mathrm{CaCO}_{3}$.

Since this type of reaction is similar to that occurring in an alkali soil to which gypsum is added, it serves as an indicator of the amount of gypsum to try. One hundred $\mathrm{ml}$ of saturated gypsum solution furnish $\mathrm{Ca}^{++}$equal to 60 m.e. $/ 100 \mathrm{gm}$ of soil when reacting with $5 \mathrm{gm}$ of soil. This is sufficient $\mathrm{Ca}^{++}$ to allow the reaction to proceed well along toward displacement of all of the sodium in all cases except those where soils are too high in both base exchange capacity and exchangeable sodium percentage. We have found that a high correlation exists between gypsum requirement and $\mathrm{Ex} \mathrm{Na}$ percentage.

The procedure for determining gypsum requirement is as follows: Prepare a saturated solution of gypsum by shaking C.P. $\mathrm{CaSO}_{4} \cdot 2 \mathrm{H}_{2} \mathrm{O}$ with distilled water. Let settle until clear, or filter. Determine $\mathrm{Ca}^{++}$in m.e./liter, using versenate titration and $\mathrm{Ca}+\mathrm{Mg}$ indicator. The concentration should 
be about 29 to 30 m.e./liter. Also record concentration as $\mathrm{ml}$ of standard $(\mathrm{N} / 100)$ versenate required to titrate $5 \mathrm{ml}$.

Place $5 \mathrm{gm}$ of the soil to be tested in a flask or bottle. Add exactly $100 \mathrm{ml}$ of the saturated gypsum solution. Stopper, and shake at intervals for 10 minutes. Filter through a folded paper. Determine $\mathrm{Ca}^{++}$plus $\mathrm{Mg}^{++}$in a $5-\mathrm{ml}$ aliquot by versenate titration, using erichrome black $\mathrm{T}$ as indicator.

Calculations are as follows: $A=\mathrm{ml} \mathrm{N} / 160$ versenate to titrate $\mathrm{Ca}^{++}$in $5 \mathrm{ml}$ of saturated gypsum solution; $\mathrm{B}=\mathrm{ml} \mathrm{N} / 100$ versenate to titrate $\mathrm{Ca}^{++}$ plus $\mathrm{Mg}^{++}$in $5 \mathrm{ml}$ of soil extract. (Since $100 \mathrm{ml}$ of saturated gypsum solution were used to extract $5 \mathrm{gm}$ of soil, $5 \mathrm{ml}$ of extract are equivalent to $0.25 \mathrm{gm}$ of soil.) (A-B) (vers. normality factor) $400=$ m.e. of $\mathrm{Ca}^{++}$adsorbed to replace $\mathrm{Na}^{+}$. (Bases other than $\mathrm{Mg}^{++}$for each $100 \mathrm{gm}$ of soil $=$ net gypsum requirement.) 1 m.e. $/ 100 \mathrm{gm}$ of net gypsum requirement $=1$ ton of 85 per cent gypsum per acre 6 inches of soil.

It is possible for this method to show a negative gypsum requirement. Such a result means that the soil sample being tested contains a calcium salt more soluble than sulfate or a soluble magnesium salt. Calcium chloride solution $(\mathrm{Ca}=30 \mathrm{~m}$.e./liter) may be substituted for the saturated gypsum solution. We have secured somewhat different results when using calcium chloride, for reasons not yet explained. A high negative value when using calcium chloride indicates a gypsiferous soil.

\section{Quick Determination of Cation Exchange Capacity}

A quick and highly accurate determination of cation exchange capacity can be made on alkali soils by an adaptation of the gypsum requirement test. It is based on saturating the soil with barium and then making the gypsum requirement test on the barium-saturated sample. The reaction runs to completion rather than to equilibrium because the $\mathrm{Ba}^{++}$replaced by $\mathrm{Ca}^{++}$from the gypsum is precipitated.

We recommend use of a $4-\mathrm{gm}$ sample instead of 5 in order to supply 75 m.e. of $\mathrm{Ca}^{++}$per $100 \mathrm{gm}$ of soil. This is sufficient for soils of very high exchange capacity. In a few cases we have had to go to lesser amounts of soil.

The procedure is as follows: Place $4 \mathrm{gm}$ of soil in a small beaker. Wet with 10 to $15 \mathrm{ml}$ of approximately normal barium chloride solution. Let marinate until small granules have disintegrated. Wash onto a plain filter paper, using a wash bottle containing $\mathrm{N} \mathrm{BaCl}_{2}$, and wash twice more with the barium chloride. Wash three times with distilled water, to a total of about $30 \mathrm{ml}$ of washings. It is necessary only to wash out the barium chloride sufficiently that the sulfate will precipitate any excess $\mathrm{Ba}^{++}$which would interfere with the titration. Dry the soil pat in the filter, and determine gypsum requirement by the usual procedure, placing soil and filter paper in the $100 \mathrm{ml}$ of saturated gypsum solution.

One precaution is necessary. Since the $\mathrm{Mg}^{++}$is practically all removed when saturating the soil with $\mathrm{Ba}^{++}$, it is advisable to add a little of some solution containing magnesium chelated to the end point in order to secure a sharp end point when using erichrome black $\mathrm{T}$ indicator. Or, a good indicator for $\mathrm{Ca}^{++}$only may be used. The calculation is the same as for gypsum 
requirement, except that 500 is used in the equation instead of 400 to adjust for the difference in size of soil sample.

The method agrees very well with the commonly used methods if applied to alkaline soils. We are studying buffers to make it applicable to acid soils, but the results to date have not been consistent.

\section{LITERATURE CITED}

BALL, JOHN

1939. Contributions to the geography of Egypt. Government Press, Cairo. 308 pp.

Bower, C. A., C. D. Moodie, P. ORTH, and F. B. GsChWEND

1954. Correlation of sugar beet yields with chemical properties of a saline-alkali soil. Soil Sci. 77: 443-51.

Cheng, K. L., and R. H. Bray

1951. Determination of calcium and magnesium in soil and plant material. Soil Sci. 72: 449-58.

Connors, J. J.

1950. Advances in chemical and colorimetric methods. Jour. Amer. Water Works Assoc. 42: 33-39.

DienL, H., C. A. Goetz, and C. C. HACK

1950. The versenate titration. Jour. Amer. Water Works Assoc. 42: 40-48.

EATON, F. M.

1950. Significance of carbonates in irrigation waters. Soil Sci. 69: 123-33.

Gracie, D. S., M. Rizk, A. Moukhtarr, and A. H. I. Moustafa

1934. The nature of soil deterioration in Egypt. Egypt Min. Agr. Tech. and Sci. Ser. Chem. Sec. Bul. 148.

Khadr Mostafa Mostafa

1953. Magnesium forms in certain Egyptian soils with special reference to effect on plants. (Master's thesis.) University of Alexandria, Egypt.

Overstreet, Roy, J. C. Martin, and H. M. King

1951. Gypsum, sulfur and sulfuric acid for reclaiming an alkali soil of the Fresno series. Hilgardia 21 (5) : 113-27.

RichaRds, L. A. (editor)

1954. Diagnosis and improvement of saline and alkali soils. U.S. Dept. Agr. Handbook 60. U.S. Govt. Print. Off., Washington, D.C.

SchoonOVER, WARREN R.

1952. Examination of soils for alkali. California Agr. Ext. Service. (Mimeo.)

1953. Examination of soils for alkali-quick tests. California Agr. Ext. Service. (Mimeo.) 
The journal Hilgardia is published at irregular intervals, in volumes of about 600 pages. The number of issues per volume varies.

Subscriptions are not sold. The periodical is sent as published only to libraries, or to institutions in foreign countries having publications to offer in exchange.

You may obtain a single copy of any issue free, as long as the supply lasts; please request by volume and issue number from:

Agricultural Publications

Room 22, Giannini Hall

University of California

Berkeley 4, California

The limit to nonresidents of California is 10 separate issues on a single order. A list of the issues still available will be sent on request. 